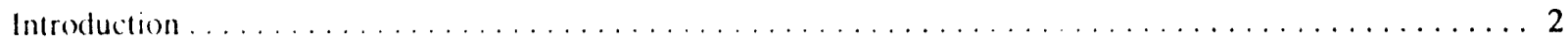

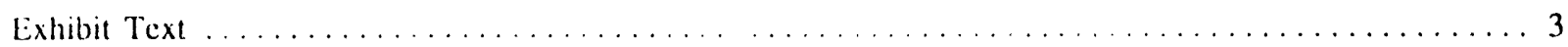

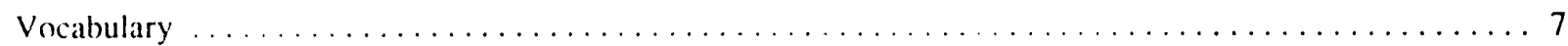

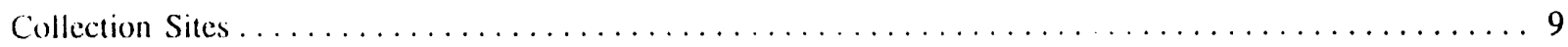

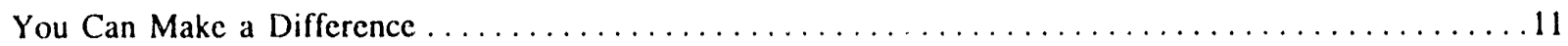

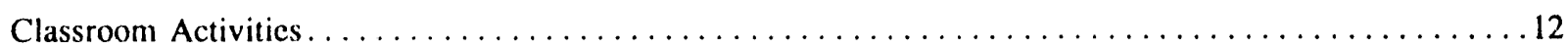

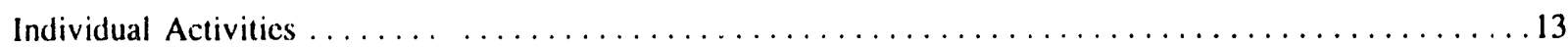

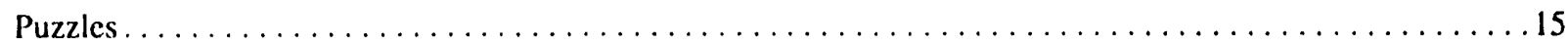

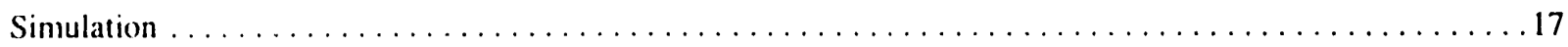

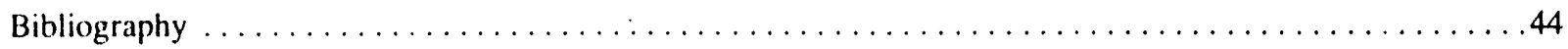

\title{
DISCLAIMER
}

This report was prepared as an account of work sponsored by an agency of the United States Government. Neither the United States Government nor any agency thereof, nor any of their employees, makes any warranty, express or implied, or assumes any legal liability or responsibility for the accuracy, completeness, or usefulness of any information, apparatus, product, or process disclosed, or represents that its use would not infringe privately owned rights. Referprocess disclosed, or represents that its use would not infricinge or service by trade name, trademark, ence herein to any specific constitute or imply its endorsement, recommanufacturer, or otherwise does not necessarily constitule or imply its endorsement the views mendation, or favoring by the United States Government or any agency theflect those of the and opinions of authors expressed herein do 


\section{RECYCLING: YOU ARE THE SOLUTION}

For the past few months, recycling has been the topic of sit-coms, magazine and newspaper articles, how-to classes, cartoon and comic strips, and editorials. In spite of all this attention to the subject, we, nationwide, are not doing that well with recycling.

Since World War II, the United States has become increasingly a "throw-away" country. Before that time, we reused everything possible. Seed and flour sacks were used for clothing and dish towels; milk was delivered in glass bottles which were returned to the dairy to be used again; paper was saved to start fires in furnaces and fireplaces and, sometimes, to wallpaper rooms; cloth handkerchiefs were used, washed, and used again. Flour, sugar and seeds no longer are packaged in cotton sacks; milk no longer comes in glass bottles. But, there are things we use only once that could be reused or recycled.

We give little thought to what we toss aside or to where it goes. The time has come when all of us have to take responsibility for our "use it once; discard it" attitudes and actions. Landfills are decreasing in number each year and the NIMBY (not in my backyard) outlook prevails. Replacement sites are not being constructed to take the place of those which are filled to capacity.

Solid waste can be dumped (as in landfills), burned (as in incinerators), or recycled. No one seems to want to live next to, behind, or in front of a landfill, so that restricts possible landfill sites to replace those facilities which are overloaded. Environmentalists are concerned about pollutants in the air as a result of burning solid wastes, which makes incineration next to impossible. That leaves recycling.

Recycling will work when a) people commit to a recycling program (either voluntary or compulsary) and b) when recycled goods are demanded by the public. The supply and demand rule is at work - if we demand, loudly and legally, more recycled products, industry will supply them. For instance, if enough people stop purchasing paper products that do not use recycled paper, more recycled paper will be used. When shopping for grecting cards, how many of us check to see if they are made from recycled material? If we remain complacent about the use of recycled goods, the supply will dwindle or be non-existent.

The three " $R$ ' $s$ " of the 90's will be REDUCE, REUSE, RECYCLE.

"Recycling is better than disposal, reuse is better than recycling.

but reduction is best of all."

Donnclla H. Mcadows

Dartmouth College (1989)

We can reduce the amount of solid waste by not buying any "disposable" products and by refusing to accept over-packaging. Many of our throwaways can be reused, maybe not in the same capacity, but reused. Some itcms which we personally might not want to reuse can be reused by others. If we reduce and reuse, there will not be as much to recycle.

Recycling is not the cure-all for all solid waste problems. There will still be a need for land-fills and/or incincrators. But, recycling can make a difference. It is up to each of us to sec that it docs.

We hope that the exhibit "Recycling: You are the Solution" will make students more aware of the need for recycling and conservation of our natural resources. 
RECYCLING: YOU ARE: THE SOLUTION

\section{RECYCLING TAKLS SOMETHING WHICH WOULD HAVE BEEN THROWN AWAY AND PUTS IT TO USE AGAIN.}

Americans produce nearly 150 million tons of residential and commercial solid waste each ycar, or slightly less than 1,400 pounds for each one of us.

Recycling salves valuable landfill space which is getting harder (1) find. Current landfills are quickly filling up and less land is now available for this use. Also, few people want to live near a latdfill. Others fear groundwater contamination by landfills. Recycling helps our fragile planet because we use its natural resoures in wiser ways than when we throw alway our waste.

Recycling also has ecomomic benefits. Some of these are:

- Tax savings because less money has to be spent on solid waste disposal.

- More efficient use of commercial incinerators.

- Less money paid to forcign nations for imported raw materials.

- Consumer demand encourages manufacturers to develop new products using recycled materials.

YOU CAN RECYCLE: newsprint . . aluminum cans . . sted cans . . glass . . plastic bottles . . yard waste.

\section{ALUMINUM CANS}

It is easy to recycle aluminum cans. Fifty pereent of the cans we use today have been recyeled. Aluminum comes from bauxite.

It costs 10 times as much to make a new aluminum can as it does to make a reprocessed can.

\section{ALSO, RECYCLING ALUMINUM USES ONLY 5\% OF THE ENERGY USED TO MAKE NEW CANS.}

\section{STELL CANS}

Recycled steel cans are used to make new sted for manufacturing. Tin is removed from the outer coating and is used to make new tin products. Tin is also an expensive and imported metal.

We produce nearly three million toms of cans per year.

\section{INDUSTRIAL MLTAL, WASTE:}

Many industries have recycled metal waste for decades. Stecl, copper, iron and tin ale examples of commonly recycled metals. 


\section{GLASS}

Glass is $100 \%$ recyclable and can be recycled again and again.

Before glass is recycled, it is crushed. Crushed glass is call "cullet." Cullet melts at a lower temperature than the raw materials of glass, so energy is saved during this manufacturing process.

Glass recycling requires two major steps - collecting and processing.

COLLECTION: Drop-off centers, buy-back centers and curbside collection are some of the ways glass is recovered. Local organizations such as churches, Scouts, garden clubs, and others support the glass recycling program by collecting glass to raise funds.

PROCESSING: In processing recycled glass, cullet is mixed with sand, soda ash, and limestone which are heated and formed into new glass.

RECYCLING ONE GLASS JAR SAVES ENOUGH ENERGY TO LIGHT A 100 WATT BULB FOR FOUR HOURS.

\section{PAPER}

Paper, especially newsprint, has been recycled for generations. Many grandparents of today's middle school students collected newsprint in recycling drives when they were young.

Newsprint recycling is still popular. In 1988, 35\% of all newspapers were collected for recycling.

The newspaper industry is a strong supporter of recycling. Many newsplapers are using recycled paper for newsprint.

Recycled newsprint can also be used to make:

- Paper towels

- Paperboard boxes

- Cellulose insulation

- Animal bedding

- Egg cartons

- Sced mulch

- Shipping stuffing

EVEN NOW, 20\% OF ALL NEWSPRINT USED BY THE KNOXVILLE NEWS-SENTINEL IS PRINTED ON RECYCLED NEWSPRINT

$\begin{array}{cc}8 \% & \text { AVERAGE LANDFILL } \\ 8 \% & 35 \% \\ \text { N } & \text { P } \\ \text { E } & \text { A } \\ \text { W } & \text { P } \\ \text { S } & \text { E } \\ \text { P } & \text { R } \\ \text { A } & \\ \text { P } & \\ \text { E } & \\ \text { R } & \end{array}$




\section{PLASTICS}

Two plastic bottles might look alike but may be made up of different chemical compounds and might have to be recycled in different ways.

The plastics industry has developed a coding system that identifies the chemical compounds in plastic to make separation and recycling faster and more efficient.

\section{SOFT DRINK PLASTIC CONTAINERS USE LESS ENERGY TO RECYCLE THAN ALUMINUM OR GLASS.}

Plastics have suffered from a bad reputation due to the fact that they are not "biodegradable," which means that they cannor be broken down in the ground by bacteria. This reputation is undeserved because plastics are very easy to recycle.

Recycled plastic can be used to make:

- Slceping bags

- Pillows

- Floor tiles

- Fibertill for jackets

- Carper backing

- Basscball bats

- Paint brushes

- Plastic building materials

\section{YARD WASTE}

Composting saves $20 \%$ of our landfill space.

When a community composts, it extends the use of its landfill for many years. The rich soil produced by composting is often sold to gardeners, or is used in flower beds of public buildings.

You can help by creating your own compost pilc.

- First, place a 6 inch layer of leaves on a six foot by six foot square.

- Next, cover with 6 inches of grass clippings along with what food waste you have available.

- Then place a layer of cow or chicken manure on top (fertilizer will also work).

Continue layering with leaves, grass, food waste, and manure until the pile is 5 feet tall, then cover with top soil. Moisten the pile thoroughly, and make sure it always stays damp. If you turn it over completely every day, you'll have compost within wecks.

Composting turns yard waste (leave, limbs, and grass clippings) and home waste, other than bones, back into soil. Over $20 \%$ of our landfills are made up of yard waste. 


\section{SOLUTION}

Recycling begins with cach one of us. We must be willing to separate glass, cans, paper, and plastics from non-recyclable trash. Companics. corporations and communitics must also commit to recycling.

A person who recycles can take pride in the fact that he or she is helping to solve a serious problem. A community that recycles can take pride in the fact that it is helping to turn a lot of its trash into valuable resources.

Once recycling becomes a part of our lives, it will be easy because it will be just another one of those things we do every dily.

These are the things we can do to start the recycling solution:

- Scparate glass, newsprint, paper, plastic and aluminum cans and take them to recycling drop off centers.

- If convenient drop off centers are not available, ask your local government to provide them.

- Buy, when possible, only those products made with recycled materials, or . .

- Buy products whose containers can be recycled.

- Condect, or be a part of, a recycling drive in your community.

- Encourage community composting. as well as stant your own compost pile.

Successful recycling programs are happening. San Jose, California processes $2,(0) 0$ tons of material per month. Almost $60 \%$ of its citizens help do this. Oak Lawn. Illinois processes $1,0(0)$ tons of material per month with $70 \%$ of its citizens participating. 


\section{VOCABULARY}

BAIING (refuse) -- a method of waste disposal in which refuse is compacted, fastened in bates (like hay), and deposited in a systematic order, reducing the amount of spate needed for disposal.

BI-METAL CAN -- A beverage container with a steel body and an aluminum top.

BIODEGRADABLE - Capable of being broken down into harmiess pieces by the action of nature (sunlight, moisture, air).

COMPOST - Layering of waste such as food scraps and grass clippings so that it decays into humus. (Sec humus)

CONSERVATION - The controlled use and systematic protection of natural resources.

CUILET - Scraps of waste glass that can be remefted and reused.

DECOMPOSE - To rot, or decay: w break down through chemical change into simple compounds.

DUMP - A site where mixed wastes are indiscriminately deposited, without regard to the protection of the environment; compare landill.

EPA - Abbreviation for the Environmental Protection Agency; the Federal agency charged with the enforcement of all Federal regulations having to do with air and water pollution, radiation and pesticide hazard, ecological rescarch, and solid waste disposal.

GARBAGE - Food that is thrown away. Wet food waste, not dry trash.

GROUNDWATER - Water below the carth's surface that fills the spaces and moves betwecn soil particles and rock. More than half of the people of the United States depend upon groundwater for their drinking water.

HAZARDOUS WASTE - Waste that is dangerous to human health and/or the cnvironment.

HDPE - High density polyethylene: a type of plastic used in making milk and water jugs.

IIUMUS -- Organic material consisting of decayed vegetable matter that provides nutrients for plants and increases the ability of the soil to retain water.

INCINERATOR - A facility designed for the controlled hurning of waste; reduces waste volume by converting waste inter gasses and a relatively small anount of ash.

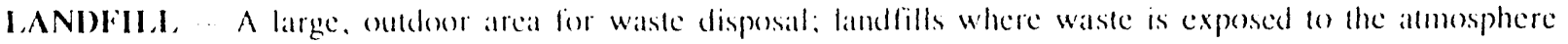
are called open dumps: in sanilary landfills. waste is layered and covered with soil.

I,ITTER - Solid waste that is generated by consumers and carelessly and improperly discarded (c.g., along roadsides or on strects and sidewalks).

I,UI,U -- Acronymi for locally Unwanted Land Use: for example, prisons, airports, and landfills.

METHANE - A colorless, odorless. Rammable, gas that is a product of the anacrobic decomposition or organic matter: call be hurned as a fucl.

NATURAI, RESOURCES - Valuable nature material such as soil, wood, air, water or mincrals.

NIMBSY - Acronym for Not in My Back Yard: refers to the fact that people wan the convenience of products and proper dispossal of the waste generated by their use of the preslucts, provided the disposal site is mot located near lhem. 
NIMEY - Acronym for Not in My Election Year; relers to the attitude of politicians concerning controversial actions during an election year.

NONBIODEGRADABLE - Not capable of being broken down by microorganisms.

ORGANIC - Composed of living or once-living matter; more broadly, composed of chemical compounds principally based on the element carbon.

OSHA - Acronym for the Occupational Safety and Health Administration: regulates and sets the standards for health and salety practices in the workplace.

PET - Abbreviation for polyethylene terephthalate: a type of plastic used in making soft drink bottles.

RECYCLE -- To separate a given waste material from other wastes and process it so that it can be used again.

REFUSE - Solid waste.

REUSE - To use something again for its original purpose; for example, returnable milk bottles are reused.

RUBBISH - A term used for soil wastes (excluding food wastes and ashes).

SANITARY LANDFLL - A land area where solid wastes are disposed of using a method that protects human health and the enviromment by spreading the waste in layers, compacting it to the smallest practical volume, and covering it with soil at the end of cach working day.

SOI.II) WASTlE - Unwanted, discarded material that does not contain enough liquid to flow cassily.

TIPPING FEE - A fee charged for waste dispossal in a landfill per given amount of waste.

THROW-AWAY IALESTYLE -- $A$ waly of living chatacterised by a high level of product consumption and discarding. especially it the products are mealln for one-time usatge.

TRASH -- Dry waste materials, not including food waste (garbage) and ashes.

WASTE - Anything that is discarded, uscless, or unwanted. 


\section{VOCABULARY}

BAIING (refuse) - a method of waste disposal in which refuse is compacted, fastened in bales (like hay), and deposited in a systematic order, reducing the amount of space needed for disposal.

BI-METAL CAN - A beverage container with a sted body and an aluminum top.

BIODEGRADABLE - Capable of being broken down into harmless pieces by the action of nature (sunlight, moislure, air).

COMPOST - Layering of waste such as food scraps and grass clippings so that it decays into humus. (Sec humus)

CONSERVATION - The controlled use and systematic protection of natural resources.

CULLET - Scraps of waste glass that can be remelted and reused.

DECOMPOSE - To rot, or decay: to break down through chemical change into simple compounds.

DUMP - A site where mixed wastes are indiscriminately deposited, without regard to the protection of the environment; compare landfill.

EPA - Abbreviation for the Environmental Protection Agency; the Federal agency charged with the enforcement of all Federal regulations having to do with air and water pollution, radiation and pesticide hazard, ecological rescarch, and solict waste disposal

GARBAGE - Food that is thrown away. Wet food waste, not dry trash.

GROUNDWATER - Water below the carth's surface that fills the spaces and moves between soil particles and rock. More than half of the people of the United States depend upon groundwater for their drinking water.

HAZARDOUS WASTE - Waste that is dangerous to human health and/or the environment.

HDPE - High density polyethylene; a type of plastic used in making milk and water jugs.

HUMUS - Organic material consisting of decayed vegetable matter that provides nutrients for plants and increases the ahility of the soil to retain water.

INCINERATOR - A facility designed for the controlled burning of waste; reduces waste volume by converting waste into gasses and a relatively small amount of ash.

1,ANDHIL, ... A large, outderer area for waste disposal, landfills where waste is exposed to the atmosphere are called open dumps: in sanitary landfills. waste is layered and covered with soil.

IITTER -. Solid waste that is gencrated by consumers and carclessly and improperly discarded (e.g.. along roadsides or on strects and sidewalks).

IULU .... Acronym for Lecally Unwanted Land Use: for example, prisons, airports, and landfills.

METHANE - A colorless, odorless, flammable, gas that is a product of the anacrobic decomposition or organic maller: can be burned at a fuel.

NATURAL, RESOURCES -- Valuable nature material such as soil, wood, air, water or minerals.

NIMBSY - Acronym for Not in My Back Yard; refers to the fact that people want the convenience of products and proper disposal of the waste gencrated by their use of the products. provided the disposal site is not focated neatr them. 


\section{IF CURBSIDE RECYCLING IS NOT AVAILABLE TO YOU, THE FOLLOWING BUSINESSES IN KNOX COUNTY COLLECT RECYCLABLES}

A-I Wiping Rag Co. 1942 Western Ave.

$521-6.580$

Aluminum, copper, brass, radiators, batterics, lead, cast iron, dye cast, stainless stecl.

\section{Alcoa Recycling Center \\ $600)$ N. Gay Sirect \\ $971-1907$ \\ Aluminum cans. \\ Central Recycling \\ 3015 N. Central Strect \\ 525-9775}

Aluminum, copper, brass, copper-brass, stainless stecl, radiators, balterics, cardboard and newspapers.

Dale Avenuc Junkyard

1214 Western Ave.

$52.3-1226$

Aluminum, copper, brass, lead and stamless steel.

Enterprise (Oil

Lexington Drive

69)(0)-9751

Waste molor ail only.

Industrial Oil Service

Crossline Road, Karns

69.3-76.27

Used motor oil or petroleum based products such as transmission thuid.

Inskip Glass Recyiling

210 Sylvia Drive

688-1.563

Aluminum cans, glass, auto batterics, plastic conlainers, rubber inner tubes, radiators, heater cores, stainless stecl, lead scrap, shect copper and scrap aluminum.

The David-Joseph Co.

2420 Schoficld St.

6.37-068.3

Sicel and molor cast.
Justin's Recycling

935 Oldham Ave.

$525-2358$

Aluminum cans, auto batteries, glass, plastic containers, rubber inner tubes, scrap aluminum, stainless stecl, copper-aluminum, copper, lead, radiators/heater cores, brass, iron and aluminum.

Knoxville Metal Corp.

822 Richards St.

6.37-4.35.3

Scrap iron, copper, brass, aluminum, aluminum cans and cast iron stecl.

\section{Knoxville Recycled Fiber}

410 Frazier SI.

$522-6129$

Newspaper, mixed paper, cardboard (corrugated), computer paper and any paper not waxed or coated.

Middlehrook Recycling

29()8 Middlcbrook Pikc

$6.37-77.39$

Aluminum cans, copper, brass, all types of aluminum, lead, batteries, stainless stecl and all mon-ferrous metals.

Paper Stock Dealers, Ins.

1111 Mitchell Si.

$524-() 3(0)$

Compuler paper, newspaper, cardboard (eorrugated), ledger paper, IBM computer cards, and aluminum cans.

Salcred Hcart Cathedral

711 Northshore Drive

$588-(0249$

Compuler paper, cardboard (corrugated), ledger paper. IBM computer cards, newspaper, and aluminum cans.

Willy's Recycling

7220 Contral Avenue Pike $947-1442$

Glass, batterics, copper, aluminum cans, brass, radiators and other aluminum. 
South Knox Recycling

430.3 Edington Road

$6.37-7739$

Aluminum cans, copper, brass, junk ballerics, non-

ferrous metals, and glass.

Southern Foundry

$2826 \mathrm{~N}$. Central St.

$524-2791$

Most metals (ferrous and non-ferrous), aluminum.

copper, brass, sted, iron appliances and junked

cars.
David Witherspoon lne.

()I Maryville Pike

$577-1613$

Cast iron, iron, tin, stainless sted, aluminum,

aluminum cans, brass, copper, and radiators.

\section{KNOX COUNTY SOLID WASTE AND RECYCLING CONVENIENCE CENTERS}

Carler, 8815 Asheville Highwaly

Halls, 6059 Maynardville Highway

Lovell Road, 119 Lovell Road

Summer hours of operation are:

Monday-Friday 9 a.m. -7 p.m.

Salurday 7 a.m. -3 p.m.

Lovell Road and Halls locations
Winter hours of operation are:

Monday-Friday 9 a.m. -7 p.m.

Salturday 7 a.m. -3 p.m.

All locations

Monday-Friday 10 a.m.-6 p.m.

Salurday 7 a.m.-.3 p.m.

Carter lociation

Aluminum cans, plastic bottles, newspaper, oil and glass aceepled.

\section{DROPOFF: CENTERS}

Krogers, 50)(3) Broadway

Buy for Less, Kingston Pike and Walker Springs

Newspapers, glass hottles and jars. aluminum calns. plastic milk jugs and clear soda bottles are aecepted.

For all locations. separate plastic solt drink bottles -- clear from green. Combine plastic milk cartons: step on them 1 o conserve space. Do not include detergent or atutemotive bottles, plastic bags or food containers with sour recyelathe plistics. 


\section{YOU CAN MAKE A DIFIERENCE}

- Recycle everything you can.

- Conserve water.

- Use cloth napkins and dish towels.

- Do not use disposable anything - razors, lighters, diapers.

- Buy fast foods al places thal use paper packaging rather than styrofoam.

- Turn off the water between welting your toothbrush and rinsing your mouth.

- Do not use pump style toothpaste.

- Use rechargcable halterics.

- Buy products packaged in glass or paper rath: , han plastic.

- Insist on paper bags or carry your own cloth bag when shopping.

- Compost.

- Buy detergent in glass bottles or paper boxes.

- Use waxed paper instead of plastic wrap.

- Buy cggs in cardboard cartons, not plastic.

- Use glass dishes and cups and metal silverware instead of plastic.

- Take a shower instead of a bath.

- Keep a bottle of water in the refrigerator rather than letting the water run until its cold. 


\section{CLASSROOM ACTIVITIES}

I. Discuss recycling and what is being done in vour community. Have the students make a list of all the things they use that could be recycled.

II. Have the students draw a picture or a series of cartoons about the need for, or value, of recycling.

III. Have a "recycling" bulletin board. Ask the students to bring in articles and/or pictures from magazines and newspapers which pertain to recycling.

IV. Have the students write a theme about the benefits of recycling.

V. Have a poster contest about recycling.

VI. Environmentalists are concerned about the use of disposable diapers. Landfills are not designed to handle fecal matcrial. There is a possibility that the feces could leach into the surrounding groundwater and contaminate it. Others say that the energy expended washing cloth diapers and the fucl used for delivery and pick-up if a diaper service is used greatly outweigh the chance of contamination of a landfill. Have the students debate the issue of cloth vs disposable diapers.

VII. Have each student write a I minute public service announcement concerring the importance of recycling. Or, have them write, direct and act in a play. If possible, videotape the activities and perform the play for the student 'yody or PTA.

VIII. Have a class discussion on what the earth will be like twenty years from now if we continue with our throw-away, one-use attitude.

IX. Start a "Recommended Purchase" list. Ask the students to make lists of products they use at home which cittier use recycled materials or are recyclable. Make a master list and post it.

$X$. It has been said that: "We don't have to worry about destroying the environment. We aren't going to destroy it and probably couldn't if we wanted to. The environment was here before us and has survived Ice Ages, etc. It will be here after we are gone! The environment will survive. We may not. We need to concern ourselves with keeping the environment suitable for human life." Have the students respond to these statements.

XI. Many stores offer a choice between plastic or paper bags. Poll your classroom. How many choose plastic; how many choose paper? Have the students select a leader from cach side to defend their positions. *Note: Students may not realize that though paper bags are biodegradable the conditions for decomposition are not present in a landfill. Plastic bags, though non-biodegradable, take up less space. Will this information make a difference in what they choose? Some are now labelled as "biodegradable" because they have had cornstarch added. Bacteria supposedly eat the cornstarch thus breaking down the plastic, but the bacteria need moisture and oxygen which are not found in landfills. *Note again: Plastic bags take up less space in a landfill than paper bags, but plastic bags are made from petroleum products. Petroleum is a nonrenewable resource. Does this fact make a difference in choices between plastic and paper bags?

XII. The symbols below make it possible to tell what products are using recycled materials and which products or containers are capable of being recycled.
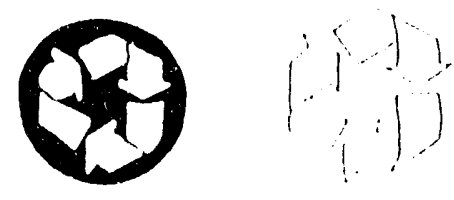

The dark circle with the three white arrows inside indicates that the product uses recycled materials. The three arrows in a circle mean that the product can be recycled.

Divide students into collecting teams and have a contest to sec how many different items each team can collect. Display them so that the students will be more aware of products which can be recycled or are made from recycled materials. Encourage use of these products. 


\section{INDIVIDUAL ACTIVITIES}

The activites below are designed to promote individual involvement in recycling. If students do not accept responsibility for their own contribution to the solid waste problems, recycling efforts will be greatly curtailed.

1. Make a search of your kitchen cabinets. Look inside boxes - cercal, cracker, cookic, cte. If the inside is gray, those boxes are made of recycled newsprint and recycled office paper. How many did you find? Swap your information with others to cncourage use of products which are packaged in recycled materials.

\section{Choose an aisle at a supermarket and make a list of those items which display a recycling symbol.}

3. Make a can-crusher. Cut down on the ar..ount of storage space needed between trips to a recyct n. collecting site. Remember to keep aluminum cans separate from "tin" cans. Sometimes it isn't easy tu tell just by looking. Use a magnet! Aluminum is not attracted by a magnet; "tin" cans (which are mainly steel) are.

\section{Materials: 2 feet of $2 \times 6$ lumber}

1 heavy duty door hinge

6 flat-head hinge screws $1 \frac{1}{2}$ inches long

1 lag-bolt $1 / 4$ inch by $1 \frac{1}{2}$ inches long

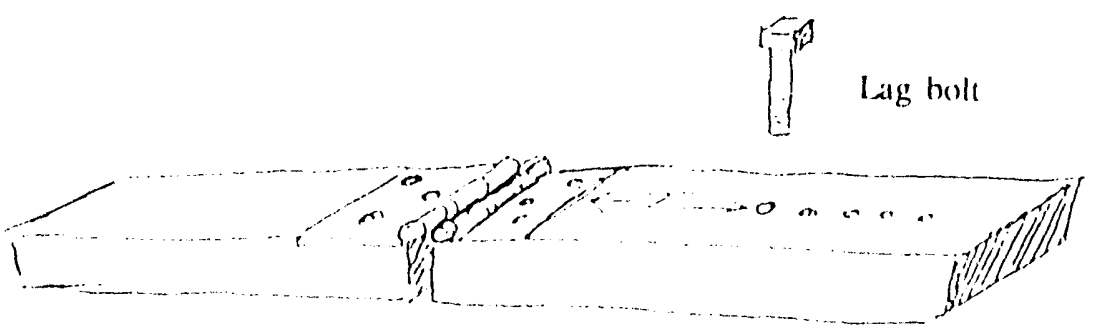

1. Position each hinge plate on the boards. (note that the hunge-pin loops extend beyond the board edges.)

2. Mark the hole locations.

3. Drill the holes and serew the plates in place.

4. Drill five holes down the center of the base board for the lag boll. Stant the holes 7 inches from the hinge cond of board and space 1 inch apart. The lag holl prevens the cans from sliding when you apply presure. Place the lag bolt in whatever hole is needed for the length of can to be crushed.

NoTl: The crusher will only be as strong as the hinge you use.

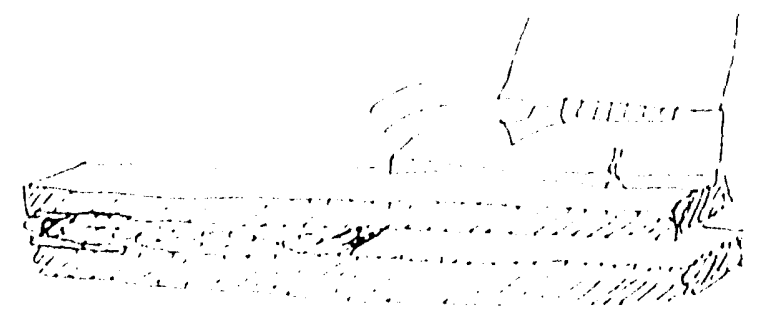

4. Do your own study of "photodegradable" plastic hags. In a remote corner of your yard, stake a

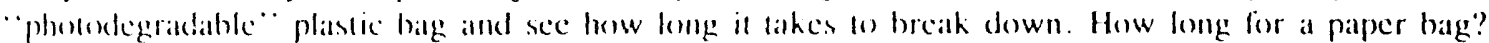

5. If your parents are not already composting. encourage them to do sol. 
6. For one week, weigh your garbage and trash daily. How much is accumulated each day? How many pounds per week does your family send to the landfill. Consider recyeling!

7. Check your toilet for leaks. Remove the tank cover and drop in 10-12 drops of red or blue food coloring. Wait about 15 minutes. Make sure the toilet isn't used while you're waiting. If colored water shows up in the bowl there's a leak. During the course of a year, a leaky toiled can waste over 22.000 gallons of water! About $20 \%$ of the toilets in homes have leaks that go unnoticed.

8. Carry a paper bag around with you at school and put all your throwaway paper in it. How much did you have after one day? After one school week? Now recycle all that paper!

9. Put some garbage and trash into a bag. Weigh it. Keep adding or subtracting until you have about 5.5 pounds. That's the average amount of garbage thrown away by each person in the United States each day. Now dump your sack and divide the items into two piles - recyclable and non-recyclable. Which pile is larger?

10. Do you keep the water running while you brush your tecth? If you are one of "those," devise a way to measure the amount of water that you don't actually use. For a family of four, how much water could be saved by turning off the faucet between wetting a toothbrush and rinsing?

11. Find out how bacteria and moisture affect soil waste. You will need a container about $1 \frac{1 / 2}{\mathrm{fect}}$ long, 1 foot wide and a few inches deep - a cardboard suit box will do. Line it with a plastic trash bag (which will be one of your test samples). Limit yourself to small, thin items such as nylon, cotton, a tin can lid, newspaper, styrofoam, paper towel, etc. Put about an inch of soil into the tray, add your samples, cover with another inch of soil, moisten with water and let Nature take its course. Add a little water each day and wait a month or so to check for decomposition.

12. Have a "trash" sale or swap. Games, toys, clothes - any item you've outgrown, or no longer use, that might end up in the can for garbage collection. Remember, your "trash" can be someone else's treasure!

13. Go to the store with your mom when she's got a big grocery list - this will take some time! Find the aisle with the soda and beer cans. Count out 250 six-packs. After counting, take a look at all those cans. That's the number of cans the average person uses every single year - and all are recyclable.

14. Help start a recycling program at your school.

15. Make a dam for your toilet. Most toilets use about four and one-half gallons of water per flush - that's more than needed and a waste of good, clean water. To decrease the amount of water used, fill a large plastic yogurt or cottage cheese container with water, put on the lid and drop in the toilet tank. Make sure that the container doesn't get in the way of the arm or chain.

16. Magazines are not good materials for recycling. But, they can be re-used. Save all magazines and take them to nursing homes, hospitals, or residential treatment centers. Can you think of other places that might want magazines? 


\section{HOW LONG; DOES IT TAKE?}

For materials to decompose, there must be sufficient water, sunlight, and bacteria. Assuming that these factors are optimum, see if you can match the time with the object.
1. Glass bottle
A. $1-5$ months
2. Wool sock
B. $200-500$ ycars
3. Tin can
C. Unknown
4. Colton T-shirt
D. 2-4 wecks
5. Laundry ticket
E. 100 years
6. Aluminum can
F. 1 year

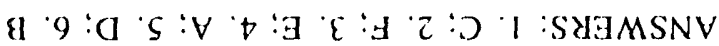

Words about recycling are hidden in the block below: See if you can find: ALUMINUM, BAUXITE, BURN, CANS, C...LET, DISPOSAL, ENVIRONMENT, COLLECT, COMPOST, GARBAGE, GLASPHALT, GLASS, INCINERATOR, LANDFILL, MAGNET, METHANE, PAPER, PLASTICS, REDUCE, REUSE, RECYCLE, TIN, SEPARATE, STEEL, TRASH, WASTE, WATER, WOOD.

$\begin{array}{cccccccccccccccc}\text { D } & \text { H } & \text { J } & \text { D } & \text { N } & \text { Q } & \text { W } & \text { T } & \text { L } & \text { A } & \text { H } & \text { P } & \text { S } & \text { A } & \text { L } & \text { G } \\ \text { S } & \text { C } & \text { O } & \text { U } & \text { Y } & \text { C } & \text { A } & \text { E } & \text { G } & \text { H } & \text { A } & \text { W } & \text { N } & \text { K } & \text { G } & \text { C } \\ \text { I } & \text { O } & \text { L } & \text { E } & \text { R } & \text { T } & \text { S } & \text { Y } & \text { A } & \text { K } & \text { E } & \text { X } & \text { A } & \text { M } & \text { J } & \text { D } \\ \text { W } & \text { N } & \text { N } & \text { G } & \text { R } & \text { O } & \text { T } & \text { A } & \text { R } & \text { E } & \text { N } & \text { I } & \text { C } & \text { N } & \text { I } & \text { R } \\ \text { Z } & \text { S } & \text { J } & \text { S } & \text { A } & \text { C } & \text { E } & \text { F } & \text { B } & \text { S } & \text { B } & \text { U } & \text { I } & \text { S } & \text { W } & \text { E } \\ \text { E } & \text { E } & \text { L } & \text { E } & \text { T } & \text { U } & \text { D } & \text { X } & \text { A } & \text { C } & \text { O } & \text { M } & \text { P } & \text { O } & \text { S } & \text { T } \\ \text { N } & \text { R } & \text { M } & \text { T } & \text { S } & \text { S } & \text { A } & \text { L } & \text { G } & \text { Z } & \text { E } & \text { O } & \text { Q } & \text { P } & \text { H } & \text { A } \\ \text { V } & \text { V } & \text { B } & \text { A } & \text { U } & \text { X } & \text { I } & \text { T } & \text { E } & \text { P } & \text { S } & \text { J } & \text { A } & \text { O } & \text { B } & \text { W } \\ \text { I } & \text { E } & \text { S } & \text { R } & \text { G } & \text { K } & \text { L } & \text { E } & \text { L } & \text { A } & \text { N } & \text { D } & \text { F } & \text { I } & \text { L } & \text { L } \\ \text { R } & \text { N } & \text { C } & \text { A } & \text { Z } & \text { N } & \text { M } & \text { L } & \text { L } & \text { P } & \text { W } & \text { Y } & \text { T } & \text { H } & \text { V } & \text { T } \\ \text { O } & \text { C } & \text { I } & \text { P } & \text { L } & \text { R } & \text { D } & \text { L } & \text { S } & \text { E } & \text { R } & \text { N } & \text { V } & \text { R } & \text { E } & \text { C } \\ \text { N } & \text { V } & \text { T } & \text { E } & \text { H } & \text { U } & \text { W } & \text { U } & \text { I } & \text { R } & \text { E } & \text { C } & \text { Y } & \text { C } & \text { L } & \text { E } \\ \text { M } & \text { R } & \text { S } & \text { S } & \text { F } & \text { B } & \text { M } & \text { C } & \text { N } & \text { P } & \text { D } & \text { Y } & \text { X } & \text { Q } & \text { A } & \text { L } \\ \text { E } & \text { P } & \text { A } & \text { U } & \text { B } & \text { O } & \text { C } & \text { I } & \text { R } & \text { E } & \text { U } & \text { S } & \text { E } & \text { T } & \text { O } & \text { L } \\ \text { N } & \text { R } & \text { L } & \text { D } & \text { L } & \text { D } & \text { T } & \text { V } & \text { N } & \text { Q } & \text { C } & \text { K } & \text { F } & \text { X } & \text { T } & \text { O } \\ \text { T } & \text { E } & \text { P } & \text { M } & \text { P } & \text { V } & \text { G } & \text { Z } & \text { R } & \text { U } & \text { E } & \text { O } & \text { L } & \text { F } & \text { B } & \text { C } \\ \text { E } & \text { N } & \text { A } & \text { H } & \text { T } & \text { E } & \text { M } & \text { A } & \text { I } & \text { B } & \text { M } & \text { A } & \text { G } & \text { N } & \text { E } & \text { T }\end{array}$


WORD SCRAMBLE

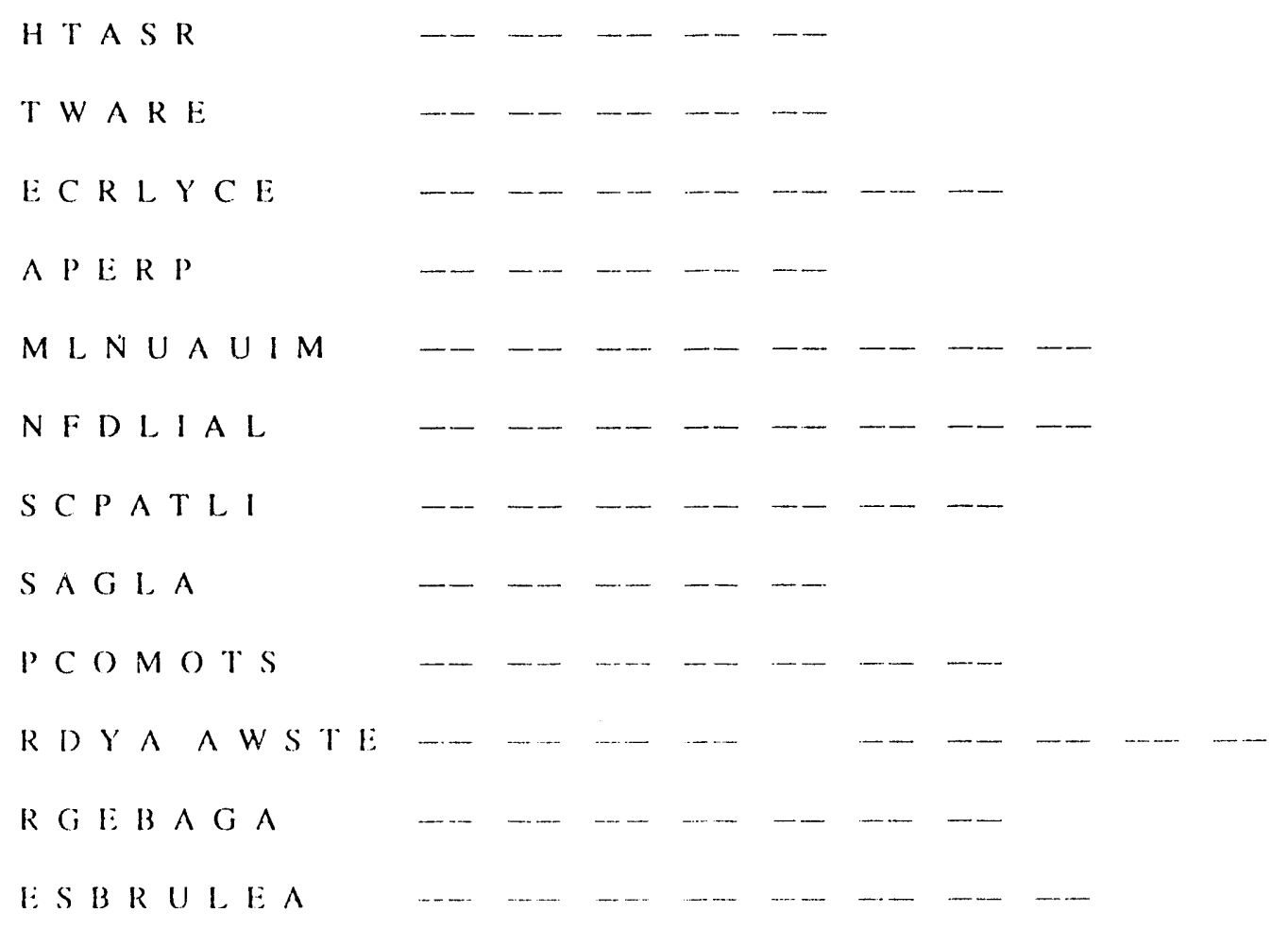




\section{CONCEPT}

Using a simulation as the culminating activity to to synthesize information regarding local waste management.

\section{OBJECTIVES}

Stuvents will be able to (1) discuss local issues and examine facts regarding waste management, (2) make decisions based upon information given and the roles played, (3) examine the consequences of decisions and actions taken, and (4) cvaluate the activity in terms of specific subject areas.
SUBJECTS: Social Studics, Science, Language Arts, and Mathematics

TIME: $2-3$ class periods (not consecutive)

\section{CURRICULUM FRAMEWORK REFER- ENCE: IV.A., B.}

KEY VOCABULARY: transfer station, disposal, landfill, recycle, reuse, exchange, hazardous waste, design capacity, tipping fec, source separation

MATERIALS: reference materials for role playing (newspaper articles, chapter factsheets, and background information from activitics in this material), a sign-up sheet (for the Open Meeting), student sheets (included)

\section{BACKGROUND}

A simulation is an enactment of a real-life situation. This activity is a simplification and partial representation of an actual experience.

Some learning occurs as a by-product of coping with the environment rather than by "trying to learn. " Similarly, during a simulation activity, facts are learned in a meaningful way because information must be organized and used rather than memorized. As a result, the teacher becomes a facilitator of learning rather than a dispenser of information. Discussion and evaluation of the enactment become valuable learning experiences for the students.

In this simulation, each student assumes a role in a representative community and responds to a crisis in waste management. Students participate in gathering information, making decisions based on that information, and examining the consequences of their decisions. By experiencing this process, students will become more interested in waste management problems that affect their lives and will understand more clearly the many factors involved in finding solutions to those problems.

As the director of the simulation, the teacher will: (a) plan the length of time for each component (adjusting stated times according to the needs of different classes); (b) select the roles most appropriate for the students (adding needed roles to the 24 roles provided); (c) assemble the resource matcrials for students, including the supplement "CRISIS IN CENTER CITY: ENGINEERING REPORT SUMMARIES," included; (d) move the simulation along when student activity slows down or refocus the class's attention when it wanders from the central theme. The teacher should assume the role of facilitator to ensure well-paced progression through the activity.

The simulation includes: (a) Introduction (background information, rolc assignments, and the mayor's news conference); (b) Open Meeting (groups plan for presentations and special commission members prepare for and preside over the meeting); (c) Decision (groups consider possible outcomes and special commission members announce decision); and (d) Evaluation (the activity and the issue in relation to the class subject area).

This activity was written and compiled by Tennessec Valley Authority and can be found in Waste: $\mathbf{A}$ Hidden Kesource.

The Resource Articles provided by the Knoxville News-Sentinel can provide background information for this Simulation activity. 


\section{PROCEDURE}

I. Introduction

A. Explain to the students that although it is important to be aware of the problems associated with waste, it is also important to understand that people perceive the problems from different points of view and that every citizen has an opportunity to present his or her viewpoint in the decision-making process. To help students understand both of these concepts, they will take part in the simulation of a crisis regarding waste disposal in a small community. The focus should be on the process involved, not right or wrong answers. Give the students an overview of the activity.

1. Each student will be assigned a role.

2. Students will participate in the decision-making process based on the information available to them and their own roles in the community.

3. The activity will require 2 or 3 class periods.

B. Distribute copies of the student sheets "CRISIS IN CENTER CITY" and the map of the county, included.

C. Tell the students they have approximately 10 minutes to read the student sheets and to list some possible solutions to the problem.

D. Ask the students the following questions.

1. What are seme ways in which the people could handle the problem?

a. List and number the answers on the board. Ask the students to paraphrase lengthy answers.

b. Do not cvaluatle the answers.

2. Which of the listed alternatives can be latheled "short-term" "? Which can be labeled "long-term".?

a. Briclly explatin what is meant by "short-term" and "fong-term."

b. [icignate "short-term" answers with the ketter "S" and "long-term," with the ketter "L."

(This activity gives students an opportunity to think through the situation before taking on alssigned roles.)

E. You may cither assign roles or allow the students 10 choose their roles. The roles represent only members of the community who will be directly affected by the decision.

1. Distribute copies of "ROLI: DESCRIPTIONS," included, to the students. Five students will assume the roles of the following special commission members.
a. Malyor, Center City
b. Member. Center City Council
c. Exccutive Judge. Prelly (iend connty 


\author{
d. Member, Counly Governing Board \\ c. Citizen-att-large
}

2. The rest of the students will assume the remaining roles. Be sure that in the selection of the roles, all three positions below are represented. Have the role cards (included) copied and cut out for the students 10 wear during the simulation. The letters of the role cards indicate the positions of the characters named on the cards.
a. M position - modify present landfill
b. P position - purchase land for new landfill
c. C position - continue hauling to Ncighboring Statc

3. Give a copy of "CRISIS IN CENTER CITY: ENGINEERING REPORT SUMMARIES," included, to each student.

F. Ask the students to prepare for the simulation.

1. The students should do the following:

a. Interview counterpart members of the community and/or teachers in various disciplines for help with their assigned roles.

b. Conduct research in the library, use classroom reference materials, or read activities in this material, "Waste: A Hidden Resource."

2. All the students should dress for their roles (at least one key item) and WEAR THEIR ROLE CARDS.

3. The students are to be prepared for the simulation on the date you determine to be best suited to your class situation (for example, next week on Monday).

II. ()pen Mecting

A. Roke cards can be pinned 10 shirts, worn around the students" necks on strings, or used in other way for identilication. The important thing is that students be identified visually with their roles.

B. Begin the news conterence.

1. Tell the mayor of center Cily that it is time for the news conference.

2. Have the mayor read the prepared statencent on the role description shect.

(: Begin formation of the coalition groups.

1. Following the news conference, inform the class that many citizens have become concerned and worricd about the news from Cily Hall 
2. In the next 20 minutes, citizens are to find others who share the same position (roles designated $\mathrm{M}, \mathrm{P}$, or $\mathrm{C}$ ) on the issuc, and they are to form coalition groups. Each group is to do the following:

a. Plan and prepare for a presentation to be made to the City/County Special Commission on Waste Management.

b. Present a clear statement of its position and support it with facts and experiences. State the impact of the problem on the lives of individual citizens.

c. Choose a spokesperson for the group. Each person in the group must identify how he or she will take part in the presentation. (Each person addressing the Commission will follow the same procedure - identify him/herself, state how the issue affects him/her, and explain his/her concern regarding the issue.)

d. The spokesperson should sign up on the sheet in preparation for the commission meeting. He/she will make most of the six-minute presentation, but other members of the group may speak. Presentations during the meeting will be made in the order that the names appear on the sign-up sheet.

D. Begin the meeting of the City/County Special Commission on Waste Management.

1. While the citizens are organizing their groups, have the five members of the Commission mecting in a separate area with the following instructions:

a. You have 20 minutes in which to develop the criteria you will use to evaluate the presentations.

b. The eriteria should include the needs of the people and the strengths and weaknesses of shortand long-term plans.

c. Develop a chart to use to record the presented facts that are important to the decision you will make. (an example appears below.)

\begin{tabular}{|c|c|}
\hline GROUP & CRITERIA FOR DECISION \\
\hline & \\
\hline & \\
\hline
\end{tabular}

d. At a specified lime following the Open Meeting, you will make a decision regarding your recommendation to the County Governing Board and (o) the City Council. Explain the reason(s) for your decision. (A response of "No decision" is mot permissible.)

2. Begin the Open Mecting.

a. At the appointed time, have the members of the Special Commission enter the room and sit facing the citizens.

b. Tell the mayor to conduct the meeting as instructed in his/her role description.

c. Alter the meeting is adjourned, tell the class that, at the beginning of the next class period, the special Commission will meet to reach its decision and will then announce the decision. 
III. Decision

A. The Special Commission makes a decision.

1. Tell the members of the Special Commission that they are to mect for 15 minutes to discuss the statements made in the Open Mecting, and they are to reach a decision regarding short-and longterm plans for waste disposal that will benefit all the people.

2. Tell the Commission members they should be prepared to announce their decision and to explain the reason(s) for their decision.

B. The coalition groups consider possible consequences.

1. While the members of the Commission are meeting, have each coalition group mee (for 1.5 minutes) (1) discuss the Commission's possible decisions.

a. Members should determine the impact that each outcome would have on their own lives.

b. Groups should examine alternative actions in the event that the decision is not favorable to their positions.

2. After this discussion, cach group should writc short statements of its response to cach of the possible decisions.

C. The Commission announces its decision and the groups respond to the decision.

1. Have a member of the City/County Special Commission on Waste Management announce the recommendation and give the reason(s) for the decision.

2. Have a member of the Commission read the evaluation critcria used in reaching the decision.

3. Have a representative from each coalition group read his/her group's statement describing how that decision will allece the lives of its members.

\section{EVALUATION}

1. Lvaluation of the activity is an extremely important part of the learning process. Work through these queslions with the students.

A. Were the Commission's criteria comprehensive? What else should have been included?

13. Were the groups responses an the possible decisions well thought out? What ofher responses could have been included!?

(. Were presentalions on the commission well prepared? Were they realistice?

1). What additional information would the citizen groups like to have had"? (List on the hoard the students" responses - for example, data regarding landfills: information about ways other communities have 
handled a similar situation; money available; educational needs; zoning restrictions; land use; or specific information about stuch alternative mantgement practices as recycling, reuse, and exchange.)

NOTE: This is an important part of the discussion because it demonstrates the need for having a variety of information and data hefore making decisions concerning waste management. A comprehensive list will include clements from the areas of social studies, science, language arts, and mathematics.

II. Another importan part of the kearning process is elating the alctivity to the issue of waste management in your community and to the suhject in your classrom. Have the students discuss the appropriate itcms below.

A. Social Studics

What are some important things to remember when making a presentation before a real decision-making board (city commission, legislature)? When is conllict healthy and constructive, and when is it bad for a secicty? Attend a mecting of your local decision-making board; note elements of effective presentations. Observe the handling of conflicting viewpoints. How were they resolved?

B. Scicnce

Develop a list of scientific information that was included in the group presentations. In the presentations, which secmed more important - scientific facts or personal interests and concerns? Was the decision reached consistent with available scientific knowledge regarding waste management? If not, explain why.

\section{Language Arts}

Write an objective article describing the simulation activity: include the three major positions that were expressed. Write a subjective article for use as an editorial. Delend the position that the decision was gond for the communty, or defiend the position that the decision was bat for the community. Include what the communty might gain or lose as a resull of this decision.

1). Mathemattics

How did the citizens use mathemattics (stattistics, projections, pereentages, eosts, or other data) in making their prescutations? How could the use of mathematics and the treatments of data (projections, exfrapolattons. or comparisons) strengthen the positions of the citizens? How could the use of clear, visual displatys conhance their presentations?

1

\section{EXTENSION}

Use the following information lo develop a second simulation regarding hazardeats waste.

Big. Wheel makes symbetic rubber and plastics for the automobile industry. It has operated an unlined disposal pond (1.5 ateres, 40 lect deep) for its industrial waste since 1945. In 1980). its waste was declatred hazardous. In 1988. management received an order lo remove the pond by dambary. 1991. 


\section{Big Wheel has three choices:}

1. Move the waste $1 .(0)()$ miles en Big Secure Hazardous Waste Landfill.

\section{A. Advantages}

1. The landlill is located far away from the community.

2. There would be no luture risk for the community.

B. Disadvantages

1. It woukd cost $\$ 13,000,000$ to dispose of the waste in the pond.

2. There would be a loss of 250 jobs due to cancellation of a marginal manufacturing process that uses (recycles) much of the waste now being generated.

3. A loss of capital would result in canceling a program to upgrade the factory and add 40 jobs.

4. The shipment of newly generated waste would cost $\$ 675,000)$ per year.

5. Transportation of the waste would be hazardous.

6. The company could be liable for cleaning up its waste at Big Secure.

11. Build an incincrator large enough to meet the 1991 deadline; then, heginning in 1992, aceept hazardous waste from other facilities. (A smaller incinerator is not feasible.)

A. Advantages

1. The cost would be $\$ 5,600,00(0)$ to dispose of waste from the pond (instead of $\$ 13,000,000)$.

2. There would be 24 new jobs crealed in order to run the incincrator.

3. Continuation of the planned company expansion would save 250 jobs and add ancther 40.

13. Disidvintilges

1. The company would have to invest $\$ 18.60(0.00)$ for an incincrator. If the company commits to this allemative. the expected obstatedes in undertaking a project of this magnitude will make it unable to mect its 1991 deatline; this would put the company in violation of a court order and may force a shutdown.

2. Wasce from other lacilitics would be transported through fown.

111. Declare bankrupley and let taxpayers clean up the site.

\section{A. Advantages}

Stockholders could take their money out of the company before it declares bankruptey and not have (1) pul up with the headaches. 


\section{1}

B. Disadvantages

1. There would be a loss of 1,100 johs. The county would be in scrious financial trouble.

2. The Federal government would have to spend $\$ 14,500,000$ to clcan up the site, and might recover only $\$ 5,000,000$ in bankruptcy court.

\section{Roles for extension:}

Plant Manager

You have no financial interest in the plant, but you will lose your job and may face legal problems if Option III takes place. You want an incinerator to dispose of the waste in the proper way and to keep your friends and neighbors employed.

\section{Chairman of Board}

You feel the plant is obsolete. You favor bankruptcy and the loss of the $\$ 5,000,000$ salvage value. You want the taxpayers to pick up the remainder of the costs. Your personal property would not be involved, and you could hide behind the corporate shield.

\section{Plant Engineer}

You feel that permitting an incinerator to be built would be a nightmare. You want to ship the hazardous waste out of the area.

\section{Citizen}

You want no waste-hauling trucks on Elm Strect. The only transportation route to the plant is Elm Street; residents do not want waste transported on their street. You are willing to compromise for two years to get rid of waste that is already at the plant, but you do not want waste transported to the incincrator from elsewhere.

\section{Local Banker}

You have made a $\$ 25,000,000$ loan to the plant. You will get nothing if the plant declares bankrupty. You also live on Elm Strect.

\section{County Executive}

Big Whecl pays 32 pereent of the county's tax revenue. Company bankruptcy would scriously hurt the county and ruin the school development program.

\section{President of Clean Air}

Clean Air is a coalition of people downwind of the proposed incinerator. They don't live in the same county or work for Big Whecl. They do not want the incinerator to be built. The group believes the waste should be shipped to a disposal site.

\section{Fire Chief}

You do not have the equipment or training to handle a major hazardous waste transportation accident. You prefer that the wastes stay onsite and be incinerated.

\section{Impacted Land Owner}

You feel that no one objected to the ponds until now. You want the waste moved away. You feel that an incincrator would make your land and house worthless. 


\section{Hysterical Mother}

You're afraid that your children will dic. You think that the wastes are poisoning your family. You insist that the "poisons" be taken away.

\section{Company Accountant}

You fecl that the company might spend all of its money on the incinerator and then still may have to clcse. You say that it isn't worth the risk. Your position is to minimize the risk and to ship the waste offsite.

\section{Company Attorney}

You feel that the greatest risks are waste transportation and the company's long-term liability if Big Secure Hazardous Waste Landfill leaks. You want to incinerate the waste onsite; damage from an incinerator is almost impossible to prove.

\section{Insurance Company Representative}

The company cannot get insurance on any of the alternatives. Big Wheel must self-insure for $\$ 2,000,000$ to run the incinerator.

\section{State Permit Engineer}

Your position is that the incinerator emplnys "state-of-the-art" technology and should work very well. A public hearing must be held before a permit can be issued. A 30-day public notice is required; a hearing must be held; a response to comments must be made; and a Commissioner's Review must follow, then possibly another round of hearings. Obtaining a permit will take one year even if there are no hitches. You understand that Big Whecl is under court order and delay would force closure of the plant. However, the process cannot be specded up. It's the law.

\section{Union President}

You place the highest priority on preventing the loss of jobs. 
Student Sheet

\section{CRISIS IN CENTER CITY}

Read the background information for Center City and then list some ways in which the people of the community might handle the problem.

The State has ordered that the Center City landfill be closed down.

\section{Background Information}

Approximately 30,000 people live in Prelly Good County:

15,000 live in Center City:

1,800 live in Hometown;

1,200 live in Smallown; and

12,000 live outside cities in the county.

Although construction of the Center City landfill has met State standards, operation of the landfill has been poorly managed.

- Industrial wastes dumped into the landfill have resulted in unpleasant odors.

- Livestock has been affected.

- Roads leading to the landfill have been littered and have become high traffic areas.

- Open burning has occurred.

- Poor operation could contaminate wells located near the landfill.

Time has run out. There is no more room; the landfill within Center City has reached its design capactiy. The people of Pretty Good County say "No" to locating a landfill outside the city limits. A makeshift transfer station has been established, and a trucking company has been hired to drive 62 miles to Neighboring State to dump the city's waste. Meanwhile Hometown. Smalltown, and Pretty Good County have also hired a trucking company to haul their waste out of state.

The waste uisposal problem has hecome a crisis in Center City. The people must make some important decisions regarding short-and long-term solutions to the problem. In the years to come, people will be living with the consequences of the decisions made today.

Record your first response to this situation by listing some ways in which the people might handle the problem. 


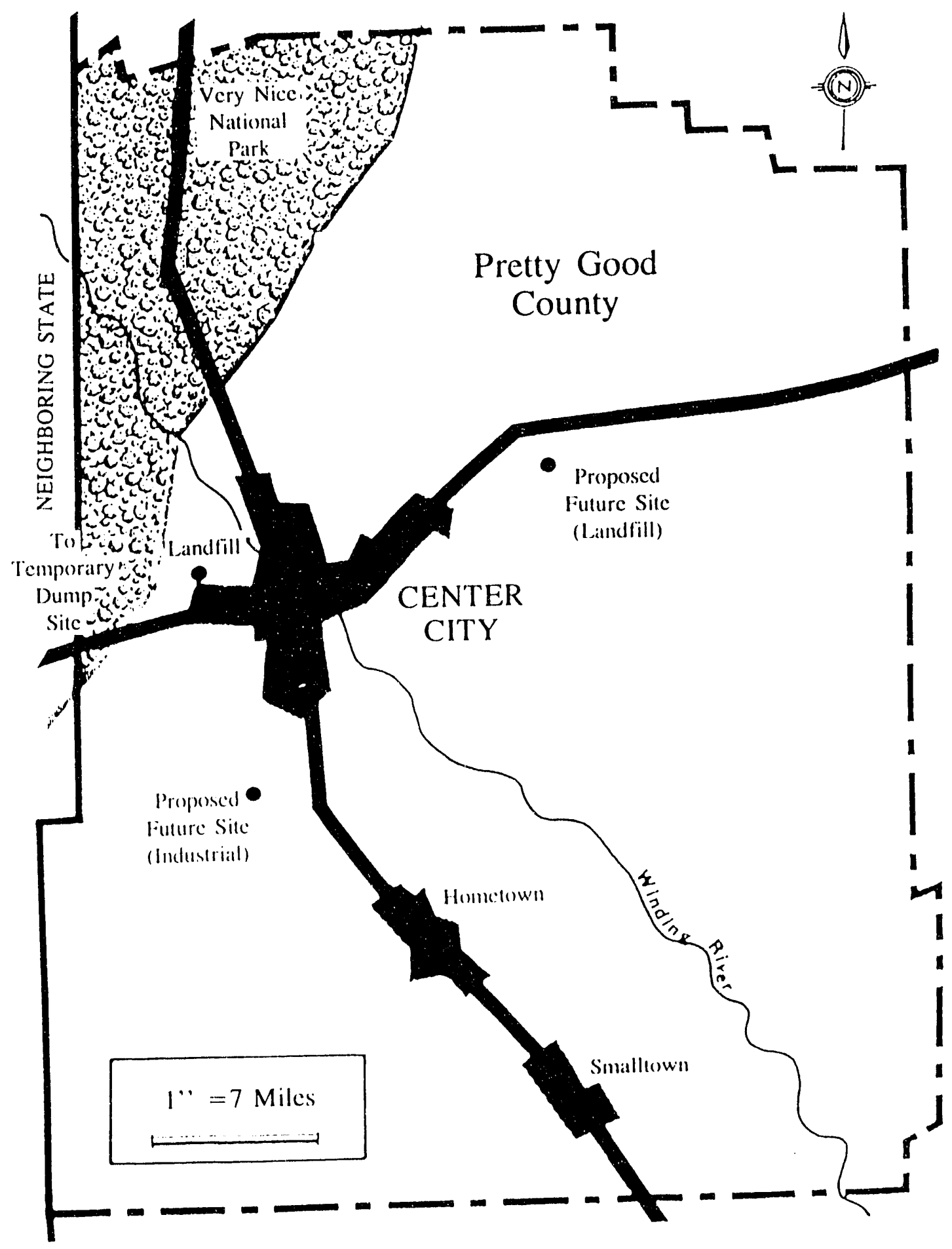




\title{
ROLE DESCRIYYTIONS
}

\author{
Handd Schaker: $\quad$ Mayor of Center City (Agc--43) \\ The mayor is the chicf elected administrative official of the city.
}

This is your first term in office and you want to do an especially noteworthy job. You want to handle this crisis in such a way that the people in your city will have cnough confidence in your leadership abilities to re-elect you in the upcoming elections. You would even like to become governor of the State someday! Your immediate responsibilities are to:

1. Hold a news conference to inform the citizens of the current crisis and what you plan to do about it. At the news conference, you will read the following statement.

"I have been notified by the State that the city landfill has been closed down. As a result of the State order, either costs will increase or the collection of trash will have to be halted, and a special fee will have to be levied for homeowners, businesses, and industries. I have been in contact with Senator Bullhorn about this problem. We are consulting with a highly qualified engineer, Planitt Wright, who has identified three possible solutions to our problem.

The first possibility is to modify the present landfill and purchase adjacent land to increase design capacity. To do this, we must purchase expensive residential propertics and install a water distribution system for the surrounding community.

The second is 10 purchase land for a new landifll. There's no room within the city and the county says 'No' to our request for land!

The third option is to continue hauling waste to a facility in Neighboring State. We are finding out that this is a very costly method of disposing of our wastes.

This is a serious problem, not easily solved. As head of the newly formed City/County Special Commission on Waste Management, I am calling a meeting, which will be open to the public, so that citizens can present their opinions regarding this crisis. The commission will then make a recommendation to city and county officials for ratification. We are secking to resolve this matter in the best interest of all the good citizens of our community."

2. Preside al the open Mecting.

a. Call the mecting 10 order.

b. Permit citizens (1) speak in the order in which they are listed on the sign-up shect.

c. Appoint a timekeper to limit each group presentation to 6 minutes.

d. Provide a 5-minute period at the end af the meeting for questions from the members of the Special Commission to the presenters.

c. Adjourn the meeting and, together with the ofher members of the Special Commission, make a decision. 


\title{
E.Z. Goahen: Member, County Governing Board (Age-55) \\ The governing board is a group of elected county residents that manages the af- fairs of the county.
}

You are usually an active member of the board but you do not have ambitions to become more involved in politics. You cnjoy the position you have now and you do only what you need to do to win the seat in election years.

You were selected to serve on this special commission because you have been on the board longer than anyone else. You like to sec everyone happy and you avoid conflict and controversy whenever possible.

You will be looking for an easy, uncomplicated solution to the problem. You go along with the majority.

\section{E. Gerr Beevir:}

\author{
Member, City Council (Age-25) \\ The City Council is a group of elected citizens that manages the affairs of the \\ cily.
}

You are a born politician. You are the youngest person ever to hold a seat on the City Council! You cnjoy solving problems and being involved with people. To you, that is where the acton is. You are very ambitious, and you plan to run for the office of Mayor when you feel the time is right. You handle yourself in such a way that people recognize how adept you are at handling problems. You are alert, pereeptive, and articulate. You know whal will influence the voters to continue their suppont of you - strong leadership with a sincere concern for their wellare.

You take a lead in asking for the specific cost factors of what is proposed.

B.A. Voatir: Executive Judge, Pretty Good Counly (Age-45)

The Executive Judge is the chicl elected administrated official of Pretly Good

County.

Sou have lived in Pretly cood County all your life. Your family has been involved in polities as long as you can remember. You know everyone in the county and call them by their first names.

fou have secn many changes in your community. A lot of folks don't like so many changes: they prefer (1) heep things the way they have al ways been. You want an improvenent of serviees (o) the county while maintaining the old values and customs.

You respect your constifuency's wishes not to locate a landlill in the county. On the other hand, if you can acyuire improved services for the county, it might be a good trade-off for allowing a landfill to be localed at a currently unused site.

You take the lead in asking speakers if they would be willing to contribute to the costs of the services they want.

O.K. Repp:
Citizen-att-Large, City/County Special Commission on Waste Management (Age--31)

The Citizen-at-Iarge holds a non-clected position and represents the residents of Pretly Good County, including those who live in the cities. 
Student Shect

You have been asked to represent the general population on the City/County Special Commission on Waste Management. You appreciate the opportunity to serve in this role because you have spent many hours working on community projects to improve the quality of life in Center City. In your business life, you try to see each one's point of view and have gained a reputation as being fair. You are not beholden to any special interest group.

At the same time, you realize the importance of this decision and how it will affect the community for years to come. You want to make a decision that will be in the best interest of all the people, including the growth of the city and the protection of the environment. You take this responsibility very seriously.

\author{
Sellitt Quick: $\quad$ Realtor $(A g c-40)$ \\ (P) \\ A realtor helps people buy or sell land or buildings.
}

You have been named repeatedly as Outstanding Realtor of the Ycar because of your aggressive techniques. You are excited about the possible move by Alliance Industries to Pretty Good County.

You have been in contact with the landowners (who reside on the East Coast) of the parcel [marked "Proposed Future Site (Industrial)" on the mapl which Alliance wants for its factory. Seymore Proffitt has just phoned you about Alliance Industrics' decision to locate its factory in Pretty Good County if the landfill problem is resolved within 30 days. You are planning to meet with the Chamber of Commerec to see that action can be taken toward settlement of the issue.

A new landfill would be attractive to new businesses.
B. Goodenough:
President, Center City Chamber of Commerce (Age-43)
(P)
The Chamber of Commerce is a council of business people that promotes the commercial sector of a community.

Alliance Industries has selected Pretty Good County as its first choice for the location of a new factory. The factory will cmploy 250 local residents for construction and production. Prelly Good County's uncmployment rate has been on the rise. The factory industry would bring in additional satellite businesses and provide growth for the area; the additional businesses would create even more jobs.

A new landlill would be attractive to new businesses and is necessary for the entire community.
Goldie Ager:
Impacted Landowner (Age-70)
(M)
This landowner is directly affected by problems resulting from the management (or mismanagement) of local waste disposal facilitics.

You are a retired high school teacher who was recently been widowed. You have lived at your current residence for 45 years. You remain active in community affairs, often voluntecring 25 hours a weck to various organizations that you feel are important to the welfare of Center City.

Although several acres separate your house from the landfill, you have encountered problems with flies, rats, and foul odors. You had not noticed any problem with the drinking water until Recllic Sharpe called one evening several weeks ago. The two of you discussed the increased fly and rat populations, the foul odors associated with the landfill, and the tremendous increase in traffic to and from the landfill along the road that runs in front of your homes. Since then you have contacted the health department and the city water department about the 
situation. Runnic Poole, a walter district representative, has been out to take water samples but has not yet returned any information to you.

You are a small voice and need to find others who feel the same about the landfill problem. You are willing (1) make telephone calls or do any other voluntecr work that would help alleviate the landfill problem.

\section{Recllic Sharpe:}

(M)
Impacted Landowner (Age--.-35)

This landowner is directly affected by the problems resulting from the management (or mismamagement) of lecial waske disposal facilitics.

You are the single parent of two elementary-age children. Your home is near the current landfill. Approximatcly six weeks ago, you noticed a discoloration of your drinking water and a great deal of sediment buildup in your kitchen sink. You contacted the local water department about the problem and were toid they would get back with you after they were able to examine water samples taken from your home. You have not yet heard from the water department.

You are fearful that you and your children may become ill from using the water. You have invested in a water filtration system for the kitchen sink to "clean" the drinking water. You contacted your neighbor, Goldie

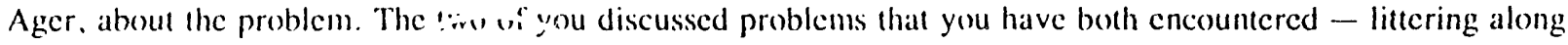
the roadside, increased th: and rat populations, and foul odors coming from the landfill.

You are glad that the landlitl has been closed, but your problem continues. You are determinited to see that the landfill is modilied and the water problems resolved.

I.M. Boss:

Pactory Worker (Age--.38)

(C)

The location of a factory worker's home is dictated by the location of relocation of the company for which he/she works.

You are a forcman in production work. You "worked your way up" to the job you have now, and you like it. You don' t want your company to move because of its being shut down or because ol its laxes being increased.

You lect the simplest. cheapest solution is 10 continue hauling watste lo Neighboring State.

D. Vide:

(P)
Cortified Public Accountant (C.PA) (Agc-So -5()$

A certilied public accountant inspects, kecps, or adjusts linancial records.

It would eost the haxpayers a lot of money to pay for the modification of the landfill that was recently closed.

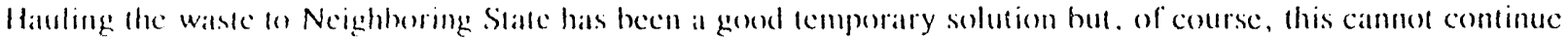
ior very longe.

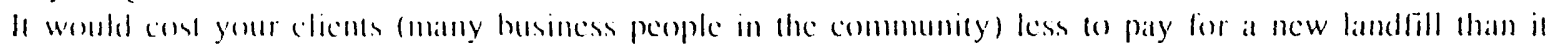

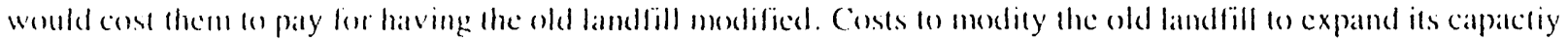
and mate is meed currem State standards make it more expensive to do than on build a new landlitl. You favor the huikding of at new landlill 


\begin{abstract}
Onthuh Line:
Factory Worker (Age-29)

(P)

A factory worker's paycheck depends on the success of the company for which he/she works.
\end{abstract}

You are new to the community. You moved to Center City from Smallown because you heard wages are better here. You are not happy about the idea of having your larger paycheck reduced because of increased taxes. (Showing the commission your paycheck lax deductions might be helpful.)

You want your company 10 stay in business; you favor the building of a new landfill.

Inthuh Dell:

Farmer (Age-49)

(M)

It is very important to farmers to maintain the agricultural heritage passed down to them by their familics.

Your land is adjacent to the present landfill. This has been a constant sourec of irritation because of increased traffic along the road on which you frequently must drive your tractors.

Additionally, five calves have been stillborn and older calves have suffered from health problems. Increased veterinary costs, high interest rates, low grain prices, and bad weather have compounded your financial problems to the point that you have become very anxious and angry. You are writing letters to the editor of the local newspaper to inform people of the major problem that exists in your area.

The existing landfill must be cleaned up!
M.A. Lerner:
Educator (Age-28)
(M)
An educator, interested in both knowledge and character, focuses on the quality of life.

As a new resident of Center City, you feel that the people of this area have not even considered reducing the amount of waste generated; they only talk about dumping it. Hauling waste to Neighboring State is a shortsighted solution. Land suitable for use as a landfill is becoming more expensive and more difficult to find.

You advocate first cleaning up and modifying the present landfill, and, second, cducating citizens about the value of reducing the amount of landfilled waste through recycling. If the quantity of landfilled waste is reduced and the present landfill cleaned up, the need for a new landfill will be lessened.

\footnotetext{
Forrest Akers: $\quad$ Manager National Park (Age-60)

(M)

A national park manager is primarily concerned with preserving and maintaining natural areas for the public to visit.
}

You have worked and lived in or near the Very Nice National Park most of your life. You have developed a program called "Save the Wildlife." This program has helped save several animal specics from extinction by providing a natural selting for their survival. Therefore. you are very angry that the city and counly have found it necessary to truck the waste through Very Nice National Park in order to dispose of it in Neighboring State. 
Trucking the waste through park territory has increased the likelihood of an accident that could cause a dangerous pollution problem for wildlife and the streams and other elements of their environment.

You would like to see the old landfill modified and an effort made by citizens to reduce the amount of waste generated.

\footnotetext{
"Handl" Handler: Owner, Handler's Hauling (Age-56)

(C)

Hating waste is one of the occupations related to the production and consumption ol goods.
}

You are currently trucking the city's waste to Neighboring State. Your truckers have encountered problems with the workers at the oul-of-state landfill. There appear to be personnel problems at the site; a strike may be possible. You own 12 rucks. four of them used for other commercial transportation necds besides waste hauling. You see increased insurance premiums and road laxes as an annoyance.

You can testify to the expenses and problems of hauling, but you don't want to lose the contract with Center City! You want lo continue hatuling to Neighboring State.

\section{Seymore Proffitt: Industrial Developer for Alliance Industries (Age-36)}

(M)

An industrial developer selects sites and oversecs the planning and construction of facilitics for new industrial development.

You have been given the responsibility of locating a site for company expansion in Pretty Good County or in another county. Financially, it is not feasible for Alliance Industrics to locate in Neighboring State because of poor road systems and the long distance from resource supplicers. Pretty Good County is closer to Alliance's resource suppliers and has a better road system for transporting the product.

Alliance Industries will contract for 50 local residents 10 construct the factory and will hire 200 local residetns (1) work on production in the new facility.

You have written a memo to the mayor of Center City confirming Pretty Good Gounty as the first choice for the new factory location. The new factory would be located at "Proposed Future Site (Industrial)" on the map. The realtor. Sellitt Quick, is handling negotiations between the site's owners and Alliance Industries.

You would like 10 see the waste disposal situation resolved as quickly as possible. Modifying the present landfill, while looking for a suitable location for a new landfill in the county, looks like the best solution.

Tieu Counts:
Certified Public Accountant (CPA) (Agc-27)

A certified public accountant inspects, kecps, or adjusts financial records.

Alliance Industries depends on your judgment regarding financial matters. The increased taxes needed to clean up the existing landfill would not be attractive to the company.

In the long term, the most advantageous solution for your client would be for the community to build a new landfill, assuring adequate service for many ycars. 
I.M. Pushin:

(M)
Environmentalist (Age-28)

An environmentalist is a person who is knowledgeable and concerned about the environment and how mismanagement affects it.

You have recently received a doctorate in Environmental Science at Alma Mater State University. You are concerned not only about the present landfill problem but also about the lack of public education in the area of waste management. People need to be informed about possible alternatives to disposing of waste in a landfill. Your main goal is to educate people about the shortsightedness of using land for waste disposal and rally them to the cause.

You feel the present landfill needs to be cleaned up immediately; discussions should be terminated regarding future land acquisitions for a landfill; and the landfilling of potentially dangerous toxic wastes should stop at once.

Ohl McDonald:

(C)
Farmer (Age-4.3)

A small increase in costs can climinate all profit for operators of small farms.

You live near the site designated on the map as "Proposed Future Site (Landfill)" and selected for a possible new landfill. You have heard that some of Inthuh Dell's livestock have had health problems, and area residents in close proximity to the current landlill have had signs that their water may be contaminated.

With rising farm costs and low grain prices, you do not want to deal with a tax increasc to cover the costs of cleaning up the old landfill and modifying it. The current arrangement with Neighboring State for waste disposal sounds good to you. You do not want to face the same problems currently facing Inthuh Dell. You are opposed (1) the proposed location for the new landfill.

Runnic Poole:

(M)
Representative, Health Department (Age--39)

The Health Department is concerned with all aspects of the health of the citizens in the community.

You have been working for the City/County Health Department for 12 years and are knowledgeable about the operation of the water treatment ficility. You sent water samples from the wells at the Ager and Sinarpe residences to the State Health Department. The State Heatth Department tested the sample and found evidence of possible contamination. Additional water samples will be required for extensive testing. Until then, it is recommended that you inform the homeowners not to use the water for consumption or for washing. At the request of the City/County Special Commission on Waste Management, you have calculated the cost of extending water lines to this community; it is $\$ 155,(0)$ ).

It is evident that the current landfill will have to be cleaned up. There might be some funds available to help with this problem. You are willing to provide data or expert testimony to help secure financial assistance. 
Slick Fleet:

(C)
Owner, Fleets Trucking Co. (Age-36)

A trucking company must invest a lot of money in equipment.

You have had your own husiness for 10 years and are eager to expand. The additional capital from a new hauling contract with the county has helped increase your flect to a total of eight trucks.

An additional increase in road lax and rising insurance premiums have necessitaled your borrowing additional monies to cover these expenses until permanent contracts can be established. You are submitting such a contract to Center City for handling its refuse.

Recent talk about a new landfill has made you anxious because of the possibitity that your contract with the county will be short-lived. With the additional overhead of several new trucks to handle the waste, you need to lobby for continued hauling.

\section{Ghetting Interest:}

(P)
Vice President, First National Bank (Age-51)

The vice presidency of a bank is a very prestigious position.

You have lived in Center City all your life and are personally concerned about the qualify of life in Center City. You are next in line for the presidency of the Bank, after Will Gain retires in 1990. You are interested in demonstrating to the Board of Directors your talent for securing important depositors and managing large accounts.

You have been working closely with the Chamber of Commerce in attracting new business to Pretty Good County. Alliance Industries is your "pet project" for the bank. You are very eager for the landfill problem to be resolved quickly.

A new landfill appears to be the answer.

Suphra Jett:

(P)
Presidem, Leaguc of Women Voters (Age---34)

The league of Women Volers is an organization whose primary goal is lo help citizens become well-intormed volers.

Sou have worked hard in Center City lo edecate citisens about candidates and issues so that they can make intelligent choices. Acquiring land for a new landfill is probably the best long-term solution, but your concern is that lhe site keatlon will be politically determined. Inflential citizens will make sure that sites near their propertics are not selecked for this purpose.

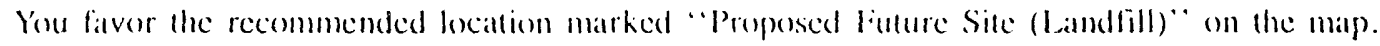




\section{CRISIS IN CENTIR CITY: ENGINEERING; REPORT SUMMARIES}

\section{WASTE CHARACTERIZATION STUIDY FOR PRETTYY GOOD COUNTY}

Last year a special lask force was organized to examine the county's waste stream (all the waste generated by human activity). To determine average waste quantitics. a weighing program was conducted for two weeks in each of the four seasons. An analysis of the waste stream focused on items that could be recyeled.

Community

Center Cily

Honctown

Smallown

Unincorporated area of county

Tolal Wastc
Waste Quantitics

(Tons per week)

328
3.5
20
87
$470(24,400)$ lons per year $)$

\section{Recyclable Content of Waste}

\begin{tabular}{|c|c|c|c|c|}
\hline Malcrial & $\begin{array}{l}\text { Amount } \\
(\mathrm{lb} / \mathrm{ton})\end{array}$ & $\begin{array}{l}\text { Recoverable* } \\
(\text { lb/lon) }\end{array}$ & $\begin{array}{c}\text { Average } \\
\text { Compaction** } \\
\text { (lbs/cu yd) }\end{array}$ & $\begin{array}{l}\text { Equivalent*** } \\
\text { (cu } \mathrm{yd} / \mathrm{ton})\end{array}$ \\
\hline Aluminum Cams & 10 & 3 & 200 & 0.015 \\
\hline Ferrous/Bimetal Cans & 120 & 35 & 600 & 0.060 \\
\hline Glass & 220 & 66 & $10(0)$ & 0.066 \\
\hline Paper/Cardboard & 600 & 180 & .500 & 0.360 \\
\hline Plastic & 100 & 30 & 200 & 0.150 \\
\hline Totals & 1.050 & 315 & & 0.651 \\
\hline
\end{tabular}

Recyclable meterials represent about 16 pereent of the waste stream by weight and about 39 percent of the waste stream hy volume.

* "Recoverable" refiers lo llose components that can be casily removed from the waste stream cither by source separatton, recycling, or conventional processing methods. The $315 \mathrm{tb}$ total indicates that 16 pereent of the counly's watsce can be catsily recycled.

** These are values that allow weights of certain components to be expressed in terms of volume. Volumes

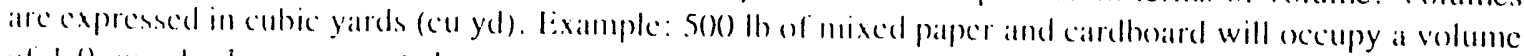
(1) l.0) cll yol when compacted.

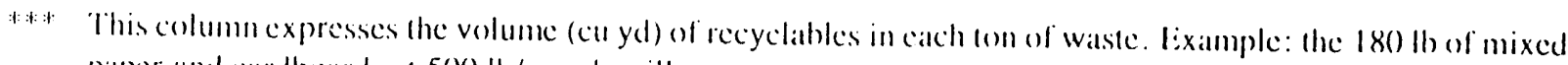
palper and cardboard. at $50(0) \mathrm{hb} / \mathrm{cu}$ yd. will occupy or represent 0.360$)$ col yd of landfill capacily. Recycling

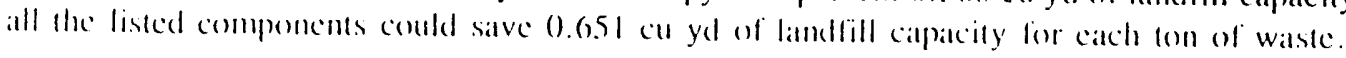




\title{
DISPOSAL ALTERNATIVES \\ (report done by Wright Enginecring Consultants, Inc.)
}

\author{
ALTERNATIVE ONE: \\ ALTERNATIVE TWO: \\ Modify Present Landfill \\ Develop New Landfill \\ ALTERNATIVE THREE: Transfer/Haul to Outastate Landfill in Neighboring Statc
}

\section{ALTERNATIVE ONE: Modify Present Landfill}

- Close out the old landfill, and cover with the required 75,000 cubic yards (cu yd) of trucked-in soil and/or material excavated from all available areas on the old landfill property.

- Purchase more land to expand landfilling operations (closeness to a subdivision limits expansion to around 20 acres - about five ycars' capacity).

- Extend water lines to each residence in the community (estimated cost $\$ 155,000$ ) so owners of the available property will honor an intent-to-sell contract for $\$ 12,000$ per acre.

- Fulfill new State disposal regulations requiring this site to have a double-liner system, a leachate collection and trealment system, a landfill gas collection system, and a complete environmental monitoring system.

- Purchase three pieces of heavy equipment to operate this expanded landfill at its optimum capacity.

Site acquisition, enginecring, and permitting

Sitc and fill arcal construction

Equipment (landfill compactor, dozer, and pan)

Community water distribution system

TOTAL, INTIAL COSTS
$\$ 320,000$

275,000

280,000

$15.000)$

$\$ 1,030,000$

Operating and maintaining the landfill will require the following:

- Seven employecs

- Major repairs and maintenance work on landlill equipment.

- Estimilled amnual operating cost of $\$ 224.00()$. (Assuming that bonds will be used to linance the initial cost.

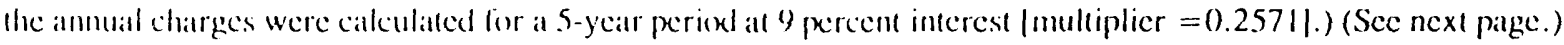

- Landfill muss be capped with a single liner when completed.

- Iandfill closure and post-closure monitoring cost of $\$ 140.000$. (Annual cost should include a sinking fund payment of $\$ 23.4(0)$ per year lo pay for landfill closure (multiplice $=0.16711$.) 
Student Shect

Sinking fund payment for closure and post care

$(\$ 140,000 \times 0.1671)$

TOTAL ANNUAL COST

$2.3,400$ (rounded)

$\$ 512,400$

- Total design capacity of the landfill is 137.800 tons of waste (compacted to $1200 \mathrm{lb}$ per cubic yard).

- Total volume capacity is $229.7(0)$ cubic yards.

- First-ycar wasteload is 24,400 tons, based on 470 lons per weck average.

- Growth in Center City and in the county is expected to caluse the wasteload to increase o percent per year for the next 10 years.

\begin{tabular}{cc} 
Projected Ycar & $\begin{array}{c}\text { Estimated Annual } \\
\text { Wasteload (tons) }\end{array}$ \\
\hline 1 & 24,400 \\
2 & 25,900 \\
3 & 27,500 \\
4 & 29,100 \\
5 & 30,900 \\
Total Capacity & 137,800
\end{tabular}

$(137,8(0) \mathrm{tons} \times 2000 \mathrm{lb} \times \mathrm{cu} \mathrm{yd}=229.700 \mathrm{cu} \mathrm{yd})$ ion $1200 \mathrm{lb}$

- Recommended tipping fee for the first year's operation is based on the annual cost estimate of $\$ 512,400$ and the estimated wasteload of 24,400 tons.

Estimated lipping fec $=\$ 512,40() / 24,4(0) \mathrm{loms}=\$ 21 \mathrm{per} \mathrm{lon}$

\section{ALTERNATIVE TWV: Develop New Landfill}

- Fulfill new state disposal regulations requiring this site to have a double-liner system, a leachate collection and treatment system, a landfill gas collection system, and a complete envirommental monitoring system.

- Purchase a 20()-alere tract of land al a yet-lo-be-disclosed location in the county (available under a no-condition sales contract).

- Plan for a 10-year serviee life of the new landfill (based on projected wasteloads).

Site acquisition, enginecring, and permituing

Sitc and fill area construction

$\$ 480 .(0)(0)$

Equipment (landfill compactor, bulldozer, and pan)

5.3()$,(0)()$

TOTAL INITIAL COSTS 280.000

$\$ 1,290,000$ 
Operating and maintaining the landfill will require the following:

- Seven employecs

- Major repairs and maintenance work on landfill equipment.

- Estimated annual cost of $\$ 224,000$. (Assuming that bonds will be used to finance the initial cost, the annual charges were calculated for a 10 -ycar period at 9 percent interest (multiplicr $=0.1558$ |)

- Landfill must be capped with a single liner when completed.

- Landfill closure and post-closure monitoring cost of $\$ 215,000$. (Annual cost should include a sinking fund payment of $\$ 14,200$ per ycar to pay for landfill closure.)

Annual operation and maintenance costs

$\$ 224,000$

Principal and interest on initial investment

$(\$ 1,290,000 \times 0.1558)$

201,000

Sinking fund payment for closure and post carc

$(\$ 215,000 \times 0.0658)$

14,200

TOTAL ANNUAL COSTS

$\$ 439,200$

- Total design capacity of the landfill is 322,900 tons of waste (compacted to 1200 lb per cubic yard).

- Total volume capacity is 538,200 cubic yards.

- First-ycar wasteload is 24,400 tons, based on 470 tons per week.

- Growth in Center City and in the county is expected to cause the wasteload to increase 6 percent per year for the next 10 years.

\begin{tabular}{cc} 
Projected Ycar & $\begin{array}{c}\text { Estimated Annual } \\
\text { Wastcload (tons) }\end{array}$ \\
\hline 1 & $24,4(0)$ \\
2 & $25,9(0)$ \\
3 & $27,50()$ \\
4 & $29,100)$ \\
5 & $30,9(0)$ \\
6 & $32,8(0)$ \\
7 & $34,8(0)$ \\
8 & $36,9(1)$ \\
9 & $39,1(0)$ \\
10 & 41,500 \\
Total Capacily & 322,900
\end{tabular}

$(322,900 \mathrm{tons} \times 2000 \mathrm{lb} \times \mathrm{cy} y \mathrm{yd}=538,2(1) \mathrm{cu} \mathrm{yd})$

ton $1200 \mathrm{lb}$ 
- Recommended tipping fee for the first year's operation is based on the annual cost estimate of $\$ 439,200$ and the estimated wasteload of 24,400$)$ cons.

Tipping lee $=\$ 4.39,2(0) / 24,400) \mathrm{tons}=\$ 18$ per $\mathrm{ton}$

\section{ALTERNATIVE THREE: Transfer/Haul to Outastate Landfill in Neighboring State}

- Consolidate waste transfer and hauling operations to prevent continued use of Outastate Landfill from becoming prohibitively expensive.

- Construct a centrally-located transfer station upon recommendation of the City/County Special Commission on Waste Management. (A transfer station is a facility that receives wastes brought in by citizens, businesses, industry, city collection trucks, and private waste collection companies. Wastes are compacted inside large tractor-trailers. One trailer holds approximately 20 tons of waste.)

Site acquisition, enginecring, and permitting

Sitc preparation

Transfer station construction

Hauling equipment (two traciors @ $\$ 60,000$ each, four trailers @ $\$ 40,000)$

TOTAL INITIAL COSTS

Opcrating and maintaining the transfer station will require the following:

- Six cimployecs (including two full-time drivers)

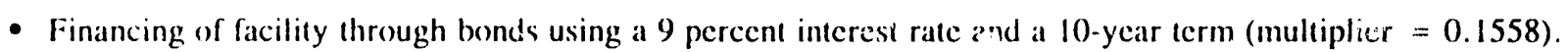

- Financing of equipment using a 9 percent interest rate and a 5 -year term (multiplicr $=0.2571$ ).

- Truck mileage of $154,8(0)$ per year, based on estimated wasteload of 470 tons per weck, 24 irips per weck, it 124 miles per rounderip.

Negotiations between the owners of Outastate Lindfill and members of the city/county commission have resulted in an agrecment:

- Outastate Landfill will agrec to take vastes, at a $\$ 9.50$ per ton tipping fec, for 5 years. (Note: Outastate Landfill is a very large disposal facility, and is operating under "old" regulations that do not require expensive liners, and other environmental protection measures. Its current disposal fee is $\$ 7.00$ per ton; the reason for the higher fee is the 5-year waste acecptance guarantec.)

- Outastate is the only disposal operation within 150 miles that would even consider taking Pretty Good County's wastes. 


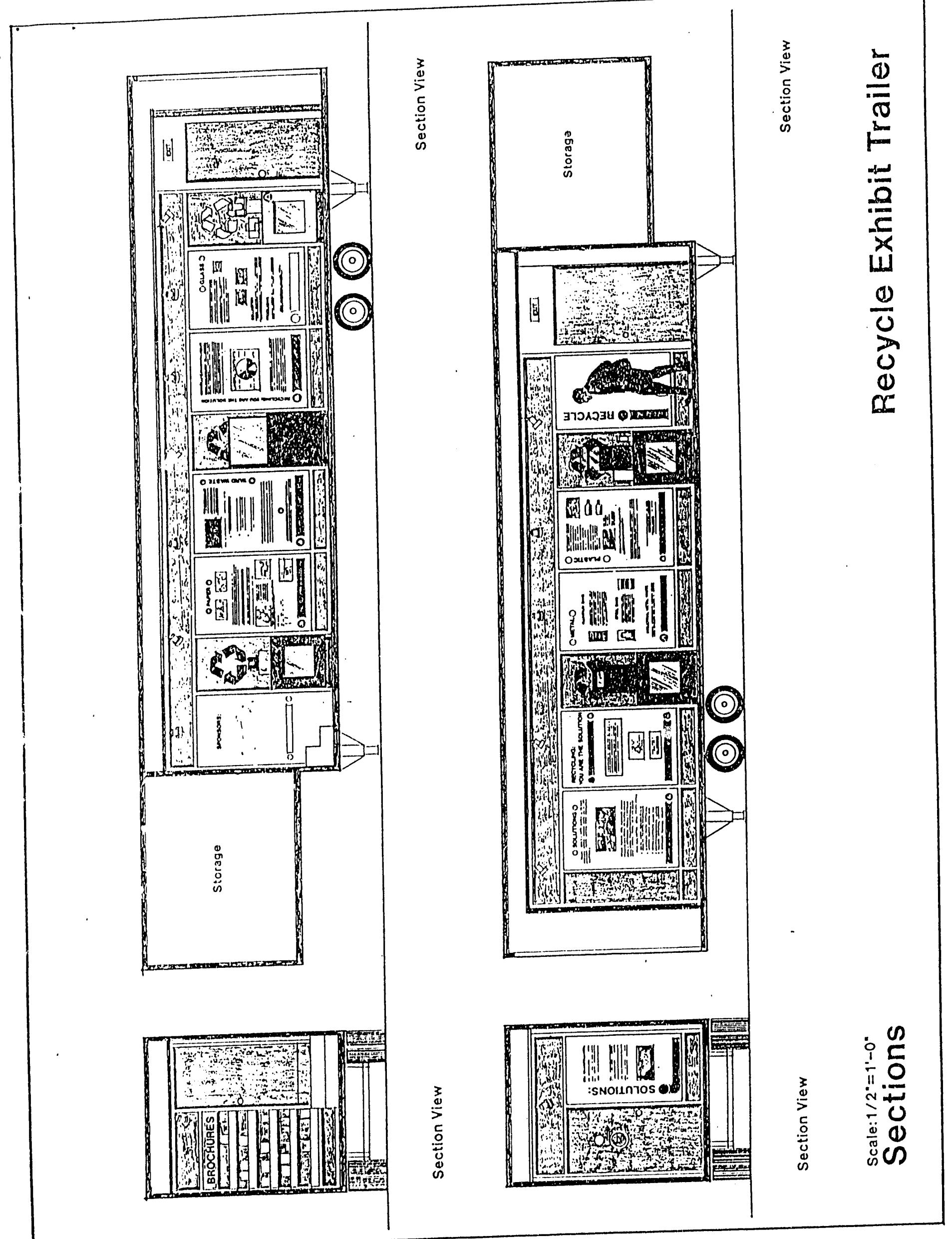




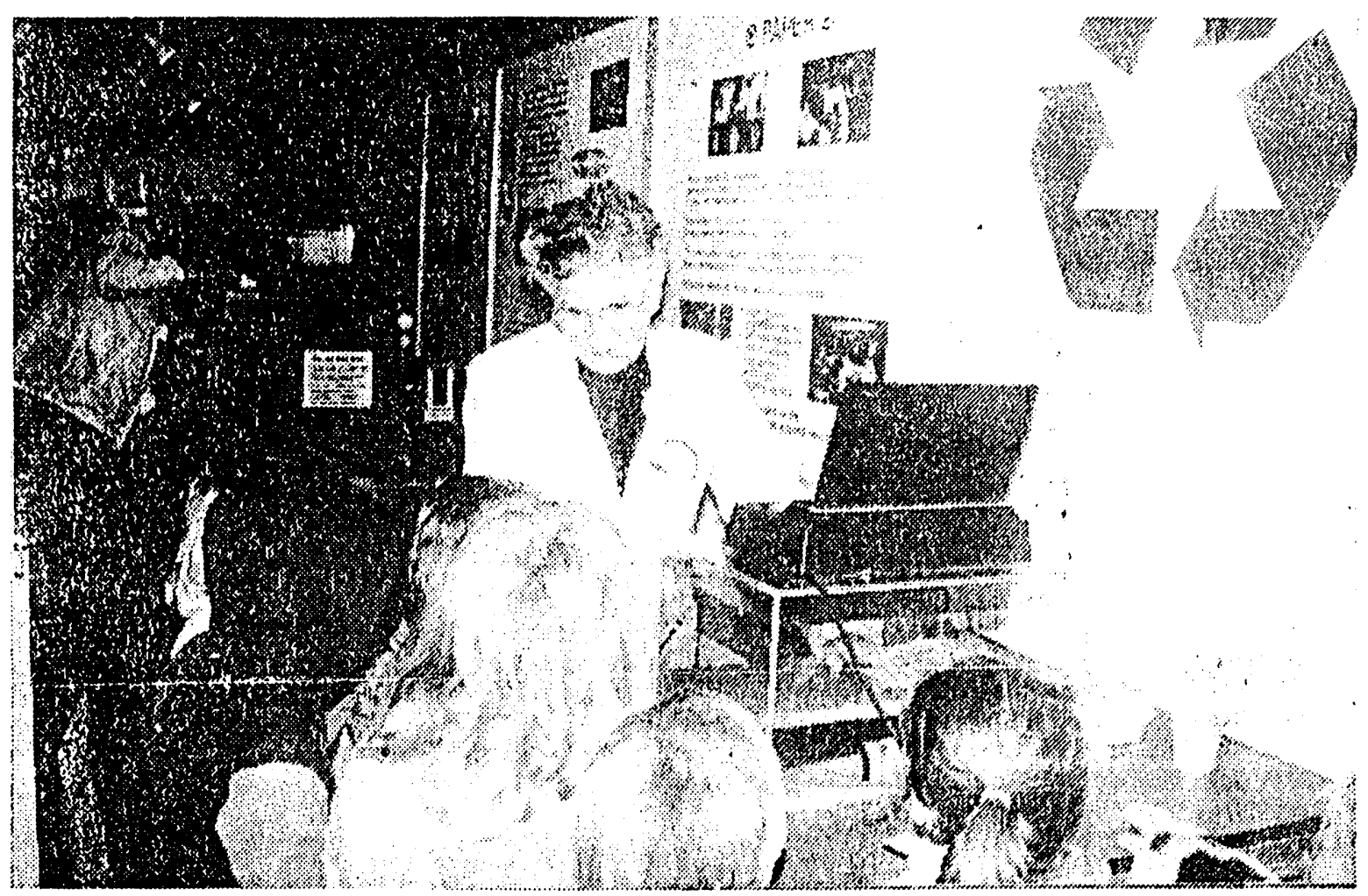

JUANITA HILL, of Bicentennial Volunteers Inc. Lalks to kindergarten and first grade students of Krista West at Fairview Elementary School on Tuesday concerning the recycling of paper. The exhibit has been seen by more than 20,000 children during this past school year.

\section{Fairview Students View Recycling Exhibit}

The Mobile Recycling Exhibit, a display shown to students at Fairview School on Tucsday, is housed in a 44-foot trailer with its own generator.

The exhibit contains a working model can crusher, plastic shredder. pilper shredder, and glass crusher. There are also wall graphices and information about the merits of recycling and the reductinil of solid waste.
Visitors to the exhibit observe and are able to participate in the shredding of paper and plastic and the crushing of glass and aluminium cans that they may be processcd for the manufacturing of products.

The MRE is scheduled to visit 20 middle schools in 10 countics in East Tennessec during the 1991. 1992 school year. Subject to the availability of funding. it will be visiting other East Tennessec schools in 1992 and 1993.

The MRE is presented by the East Tennessee Discovery Center and is sponsored by the Roddy

Coca-Cola Bottling Company, Knoxville News-Sentinel, Tennessec Valley Authority, . Department of Energy, and Bicentennial Voluntecrs Inc., which operates and staffs the exhibit.

\section{Three SHS Football Players Named All-District}

Three players from Scoll High have been selected to the All.District Seven (AA) fox)tball team.

Farning positions on the honor syuad are: Steve Watters, senior lailback lincbacker: Jason Terry, senior quarterback defensive back: innd Mare Serra, senior offensive guard defensive end.

Other honorees include:

Kingston-Aaron Roberts, Stacey M(x)re, Travis Baker, Byron W(x)ds. Jamic Millican. and Mike Boles.

Rockwood.. K slvin Inman.

Stephen Jolnson, Clinton Foland. Eric Bowman, Robbic Newby.
Jamic Presley, and Jason Eskridge (MVP).

Warıburg..Jay Moorc.' Brandon Pelers, and Mall Vespic.

Harriman.. Wayne Bullard, Steve Gresham, and Mikc Lewis.

Oliver Springs..Nathan James, Wendell Jones, and Dewayne Butler.

\section{Former RSCC Athletes Invited To Event}

All former Roanc State (ommunity College athletes, coaches, and cheericaders are being invited to allend the Roanc Stalc/Monlow State basketball game on Salurday. February 8.

$A$ reception and special

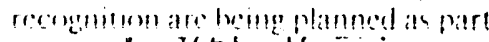

of Roanc Statc's 20th Ammiersary Colcbration.

Roanc State athletes and coaches have won division, stale, regional and national tilles in men's and women's baskelball, baschall, men's and women's lenmis, and golf. who helped make Roanc Siate's athletic programs so successful on the playing ficlds as well as in the classrocoms.

The Radiderelles will face the Mollow State lady Buchs at 6 p.m. and the men's game will follow all 8 i' '!! 


\section{itudents see bemefits of recycing}

\section{IIY JIM ISENNEDY}

THE MERITs OF recycling and the reduction of solld wastc were brought home to school chlldren in Madisonville this weck by a lourlng cxhlblt.

It is called the Moblle Recycling Exhiblt and is housed in a trailer 44 feet long.

The cxhlbit has a working model can crusher. plastlc shredder, paper shredeler and glass crusher. In addition. there arc tvall graphics and information cxplaluing the benclits of recycllng.

Childicn entered the exhibit in small groups and were gulded by voluntcers from Biccntennlal Voluntecrs, Inc. from Knoxvllle.

The operation of each devlce was demonstrated. The children partlclpated in the sinredeling of paper and plastic. the crushing of glass and aluminfum cans.

The chlidren were told that cach of llic matcrials used in the demonstration can be used in the manufacturing of products.

"AIORE TILATY 13,000 children have already seen the dlisplay. and our isoal for llie end of this ycar is for 60,000 lo sce It." sald Jean Demonbcum, a volunlecer.

lhe exhiblt is schecluled to visil 20) dilferent middle schools III 10 rnumlles in last Tennessec durlng the 1991-92 school ycar.

According to Demonbcum. a rollred Tenmessec Valley $\mathrm{Au}$ fliority cmployce. If the funds ile avaliable next ycar, the projeel will conllnue.

As the chlldren enter lhe exhlblt. Hhey are shown how cach machlne works. Volunlecrs lake stmple boltles and cans ind linsert them Into lise varlous rlevlecs.

By allowing the kids to sce low Irash ean become lisclul law inalcrial. llic sponsors hope (1) encolltage llic valuc of recyclings.

litic exlibit is presented by llic "Eitst liennessec DIscovery Cenler." and is sponsored by Roddy ronea-Cola Hottlitis Complaty. Hic Knoxville NewsSenllucl, the leunessec Valley Authorlly. Hlic U.S. Department , of Encrsy and Blcculcumal Volunlecers, inc.
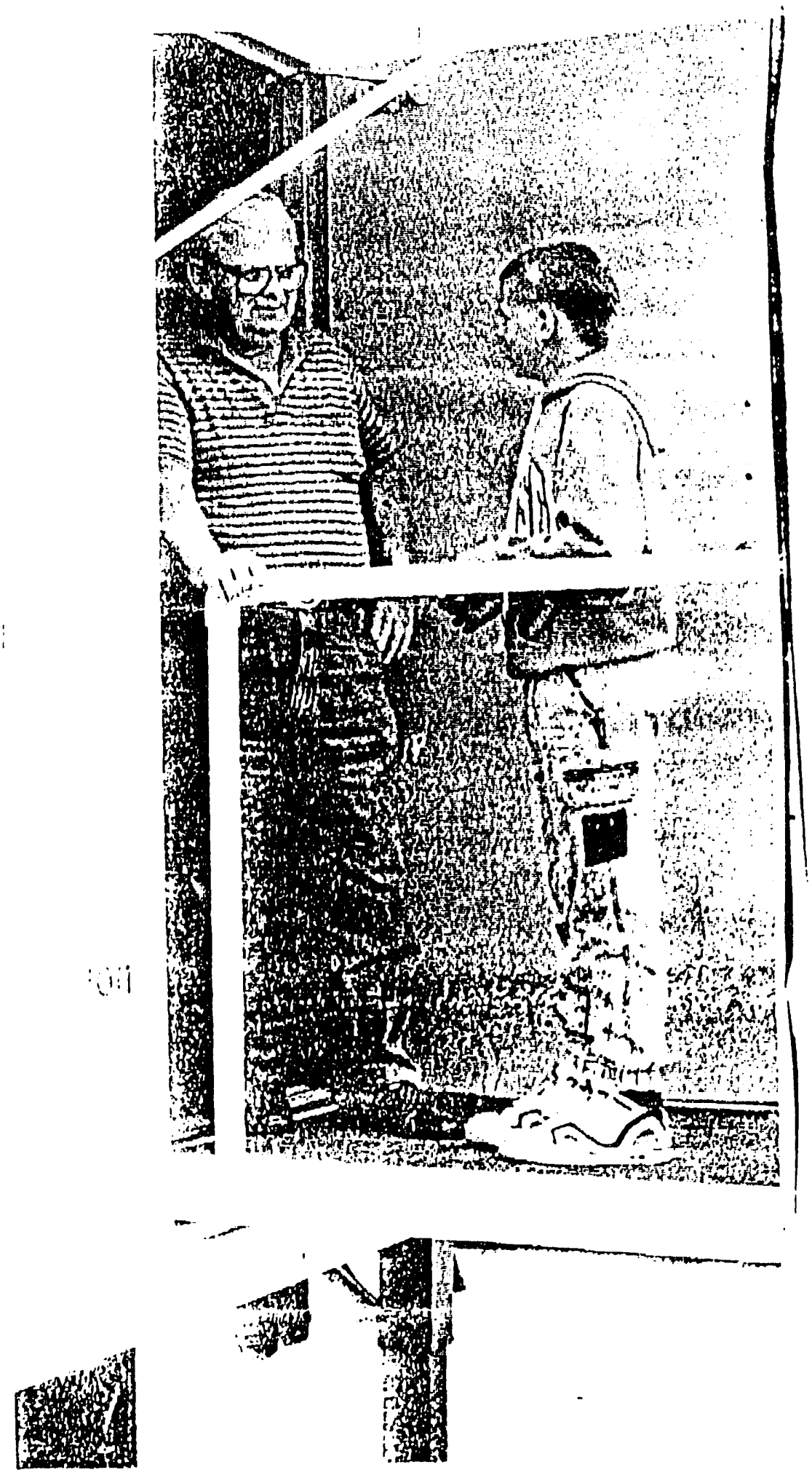

ROY SLIGER, an Aehens volunteer with Bicentennial Volunteers, Inc. iVelcomes Madisonville Middle School 5 thgrader James Glen IScy into the Mobile Recycling Exhibit Wednesday. I'hoto by Jim Kennedy 
4-The Demecrat andTellice Laker - Frlday, Nov. 22, 1991

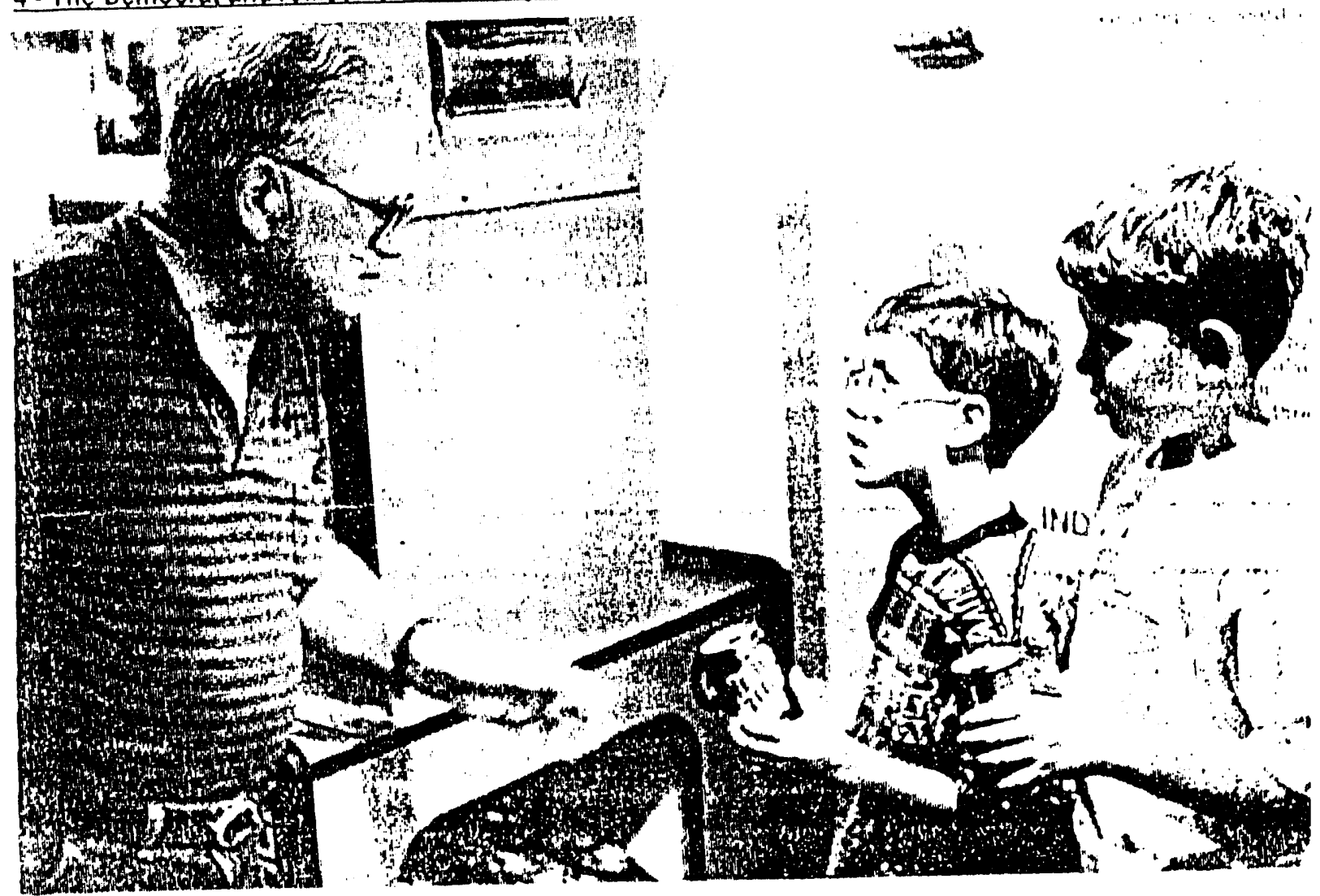

SDTH GRADE students Jeremy Brewer, left, and Nicky Toomey ask retired volunteer Roy Sliger about the aluminium can crushing machine. The two boys, along with other Madisonville Middle School students toured the Mobile Recycling Exhibit Wednesday. 


\section{Students take a closer look at recycling devices}

Area students can $\mathrm{gel}$ a close look at recycling equipment when thic East Tennessce Discovery Center's mobile recycling cxhibit makes appearances at their schools this ycar.

Students at Robertsville Junior High will be invited to put their hands on recycling cquipment featured in the mobile display when it appears at their school Oct. 7-12. Students at Jefferson Junior High will have the samc opportunity $\mathrm{Ocl}$. 14-19.

The exhibit, permancntly housed in a 44-foot trailer, contains displays of a glass cruncher, plastic shredder, can crusher, paper shredder and photos of a compost pilc. The trailer shows up at the intended school on a Monday, the display is set up, and visitors tour the cxhibits from Tucsday to Saturday, according to a news relcasc from the Discovery Center.

The trailer appeared at Clinton Middle School last month, marking the debut of its tour for this school ycilr. Visits to schools in Union, Anderson, Loudon, Monroc, Blounl, Sevicr, Hamblen and Grangicr countics are planned for the mobilc educational unit this ycar.
The traveling cxhibit was madc possible by a $\$ 50,000$ grant from the U.S. Department of Encrgy and sponsorship by the Tennessce Vallcy Authority.

Other sponsors include the Roddy Coca-Cola Bollling Co. and the Knoxville News-Sentincl Co. The cxhibil toured all Knox County middlc schools last ycar.

The trailer features handicapped access, the relcase said, and the $\mathrm{cx}$ hibit is operated by TVA Bicentennial Voluntecrs.

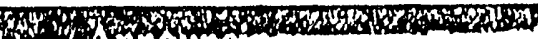

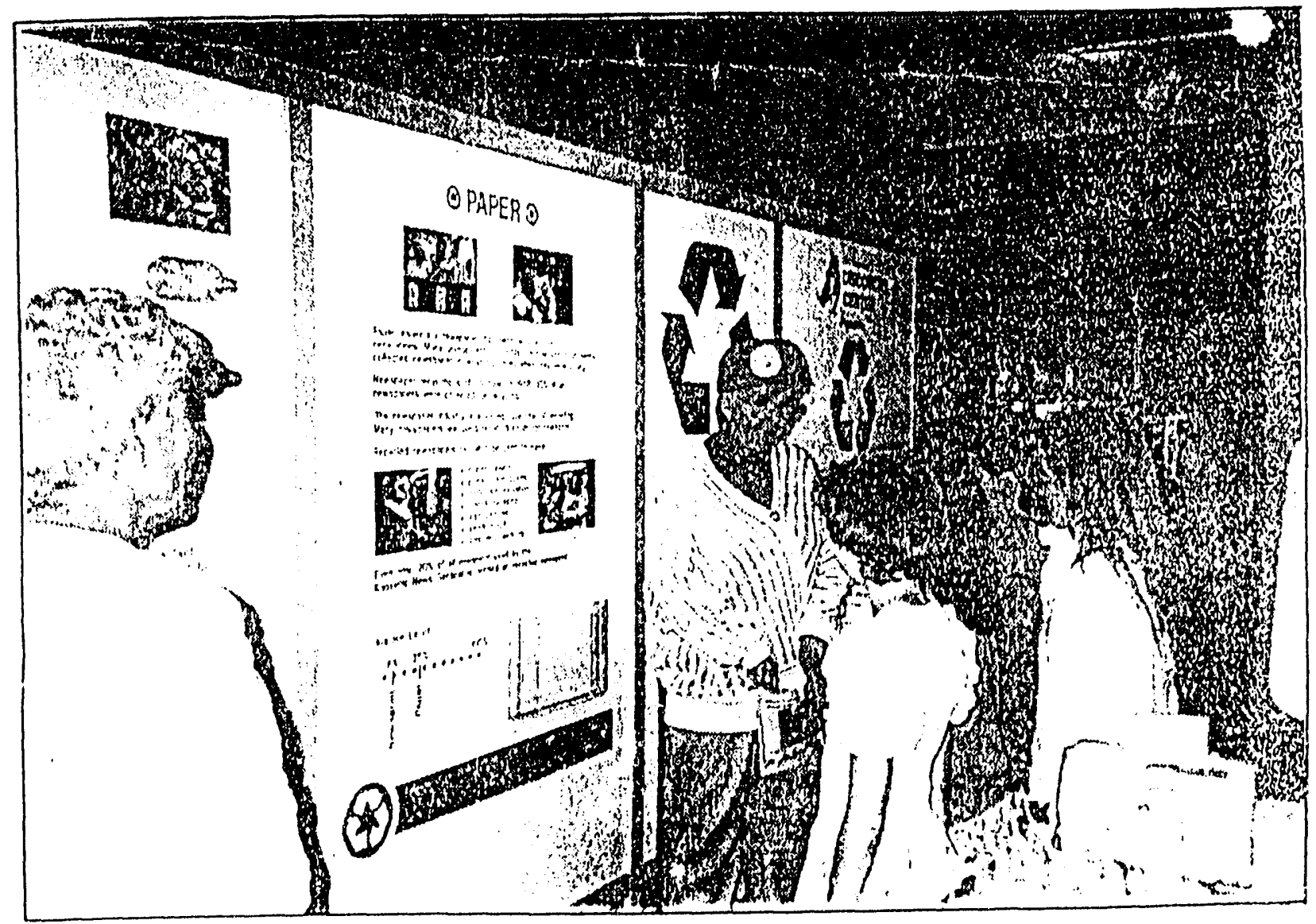

The Couricr-News / WIRICIA IIUUISX

\section{Recycling exhibit at Clinton Middle}

JUANITA HILL OF KINGSTON speaks to Clinton Middle School sixth-grade students alout recycling. Hill is a member of the Bicentennial Voluntecrs Inc., onc of the sponsors of the recycling! exhibit at the school. The exhibit, from Tuesday to Thursday, includes glatss, paper and platsic;

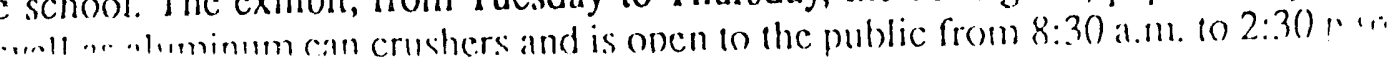


, ca.

\title{
Recycling exhibition visits L.C.E.S, L.C.M.S.
}

\author{
$\wedge$ traveling recyclingi brought thetr own cans to \\ cxhiblt came to the local inhol and walched them \\ clementary and miclde feet scpuashed. \\ schools lasl weck \\ All of the sturients at of l.C.E.E.S. sald Friday that \\ L.C.E.S. and L.C.M.S. were lin ronsidered the venture \\ sece firshiand how \\ paper, glass, alum 1 num \\ cans, and plastic can be \\ recycled. \\ Many of the students \\ in be very Important and \\ crlucatlonal. \\ "I wish lake Clly could \\ ficel something like this \\ slarled. \\ - Righi now, fl's the \\ imronvenience that is \\ kecpinf' people from \\ dioing it. If you could make \\ 11 more convenient, people \\ would do $11 .-$ (7he nearest \\ ricycilng bins are in Oak $C$ \\ Ridge or Norris) \\ IImporlant wilh cach new \\ yiar because the lancinils 1 \\ aic filling up." sald t! \\ Miadron.
}

\section{Recycling display at Maynardville Elementary}

With space for landfills scoming much harder to find he East Tennessec Discovery cnter has begun an cducational rogram for students. They rought a 44' trailer cquipped ith replica's of recycling achines 10 Maynardville Iementary School for throe days st weck. The recycling program sponsored by Roddy Coca-Cola O. Knoxville News Sentincl, U

Depl. of Encrgy, TVA and icentennial Voluniccrs. Lconard nd Jcan DeMonbreun and fartha Allen are voluntecrs and avel with the unit.

Deborats Lay, sixth grade social udies leacher al M.E.S. is the oordinator of the recyeling rogram now in operation at the chool. Ms. Lay said "l'm trying to ach the children that one person an make is diference when they rork lopedher and each others to ecrele. Vincty percent of the

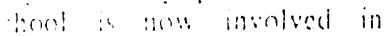

real landfill's, if we can find the space," she said.

Today, there are more types of solid wastcs that arc recyclable than there was in the lyo(s. In addition to paper and glass, cans

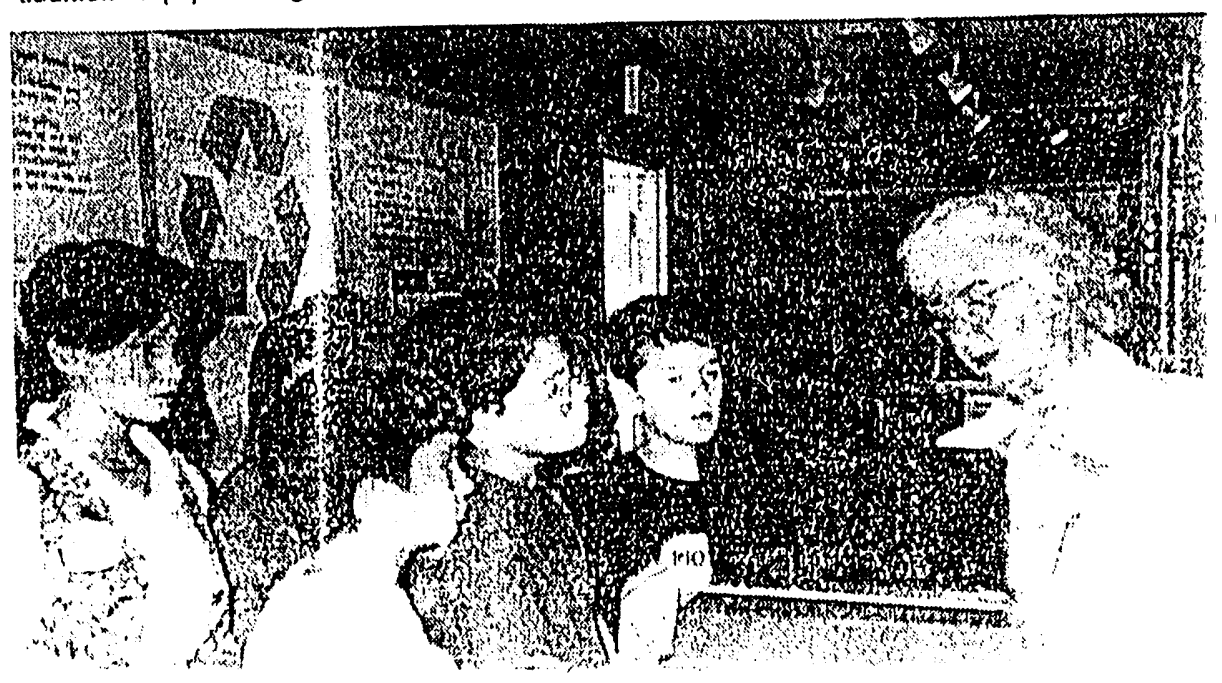

and somc plastics can be madc into usable products. Robert Miller is Operations ion Company in charge of ion Company in charge of

"complimented ihe stude: MES on being very well bc and cooperative." Ninety secn the display and the beforc year's end is 59,000 manager with Halscy Constructhundred students have a:! 


\section{Recycling display at Maynardville Elementary}

With space for landfills scoming much harder 10 find he East Tennessec Discovery cnter has begun an educational rogram for students. They rought a $44^{\prime}$ trailer equipped ith replica's of recycling lachines 10 Maynardville Iementary School for three days ist weck. Thie recycling program sponsored by Roddy Coca-Coli o., Knoxville News Scutincl, U. Dept, of Encrgy, TVA and centennial Voluntecrs. Lconard nd Jcan DeMonbreun anc 1artha Alien are voluniecrs and avel with the unit.

Deborah Lay, sixth grade social ludics leacher at M.E.S. is the ondinator of the recycling rogram now in opcration at the chool. Ms. Lay said "I'm trying to ach the children that one person in make a difference when they vork logether and teach others to ecycle. Nincly percent of the chool is now involved in ccycling and Alcon picks up our luminum cans that arc bcing aved throughout the school." eccently her class had a project or each student to take an ilcm ind make it to something clsc, as a vay of understanding recycling.

"Plans are for the class to do ample landfill project to sec what mannmeto the inemcthat are nut in real landfill's, if we can find the space," she silid.

Today, there are more types of solicl wistes that are recyclable than there was in the 1960)'s. In addition to paper and gliass, cans

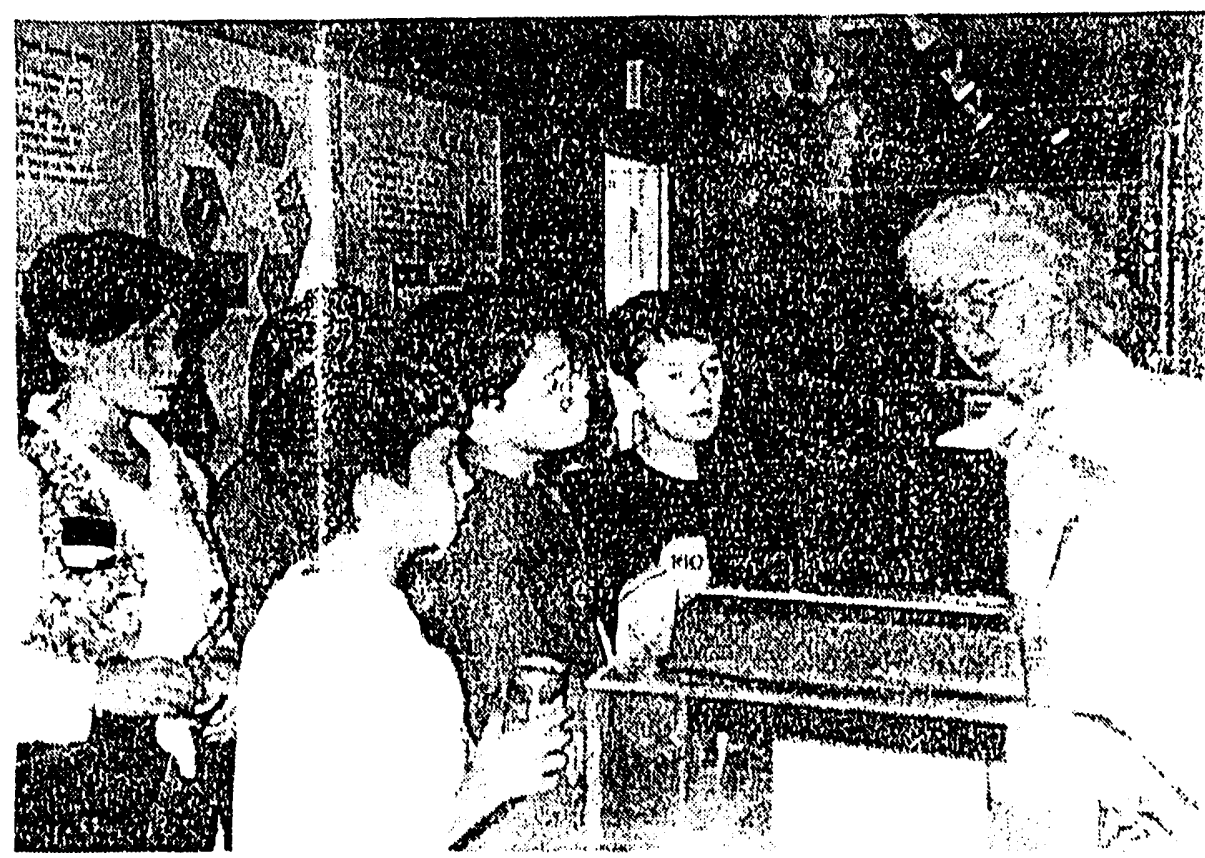

Shown are 5 th grade sludents of Ms. Carolyn Murr as they obscrve how paper is being shredded in preparation for recycling. Mrs. Jean DeMonbreyn shows the sludents how it operates and answers, questions.

and some plastics can be made into usablc products.

Robert Miller is Operations manager with Halscy Construction Company in charge of booking the display. Mr. Mille "Mes on being very" well be hundred students have a seen the display and th

$$
\text { a }
$$



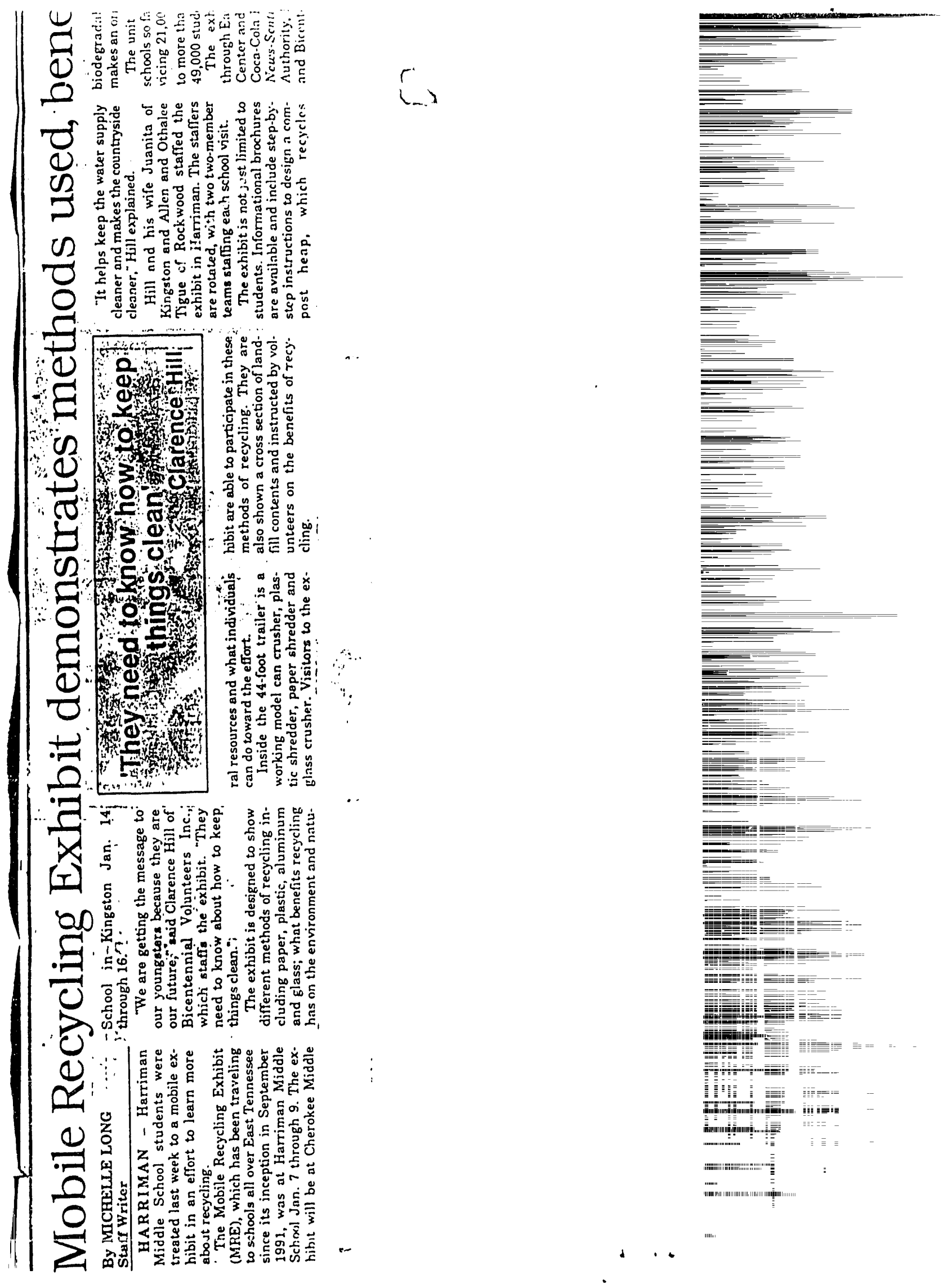


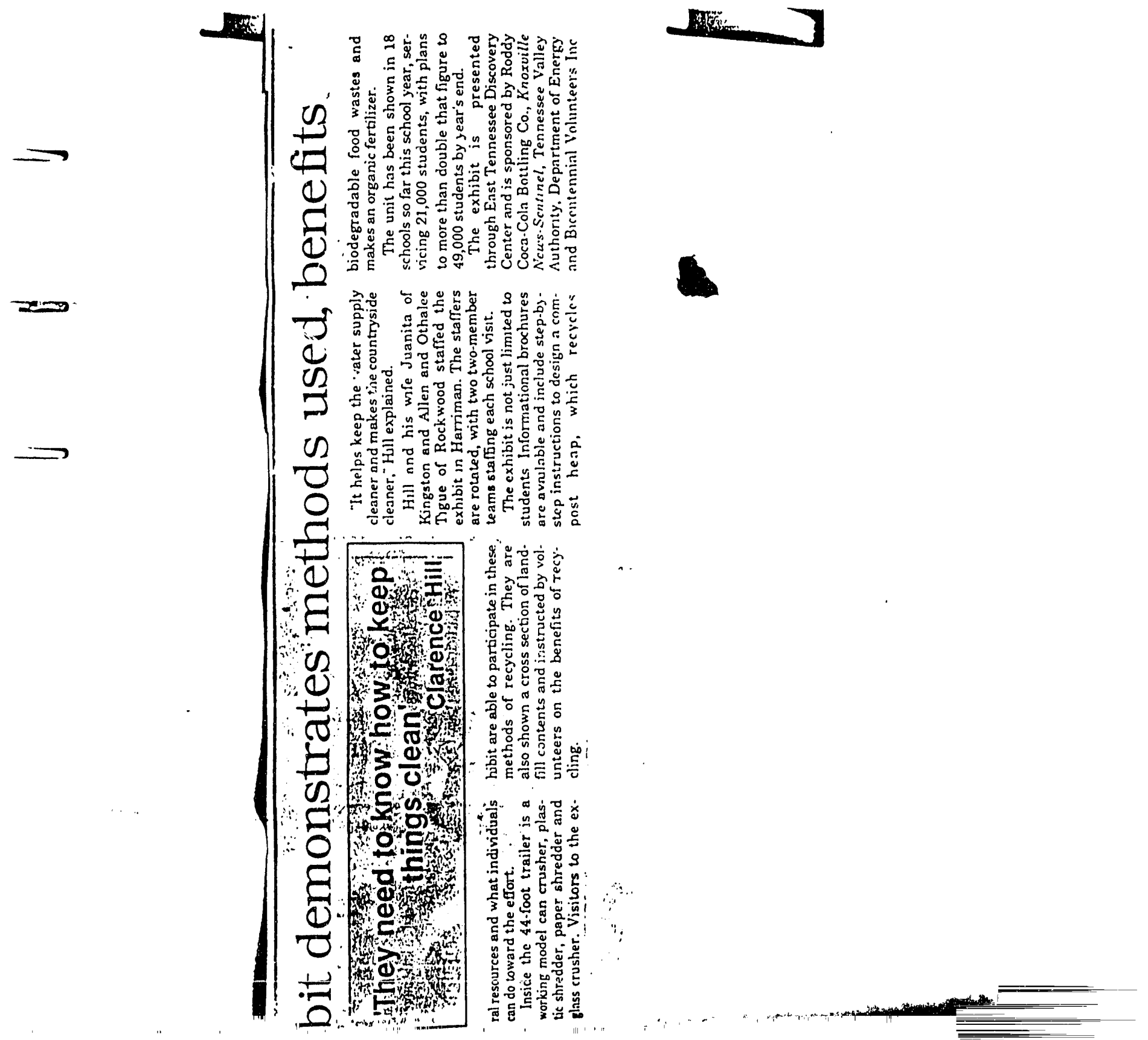



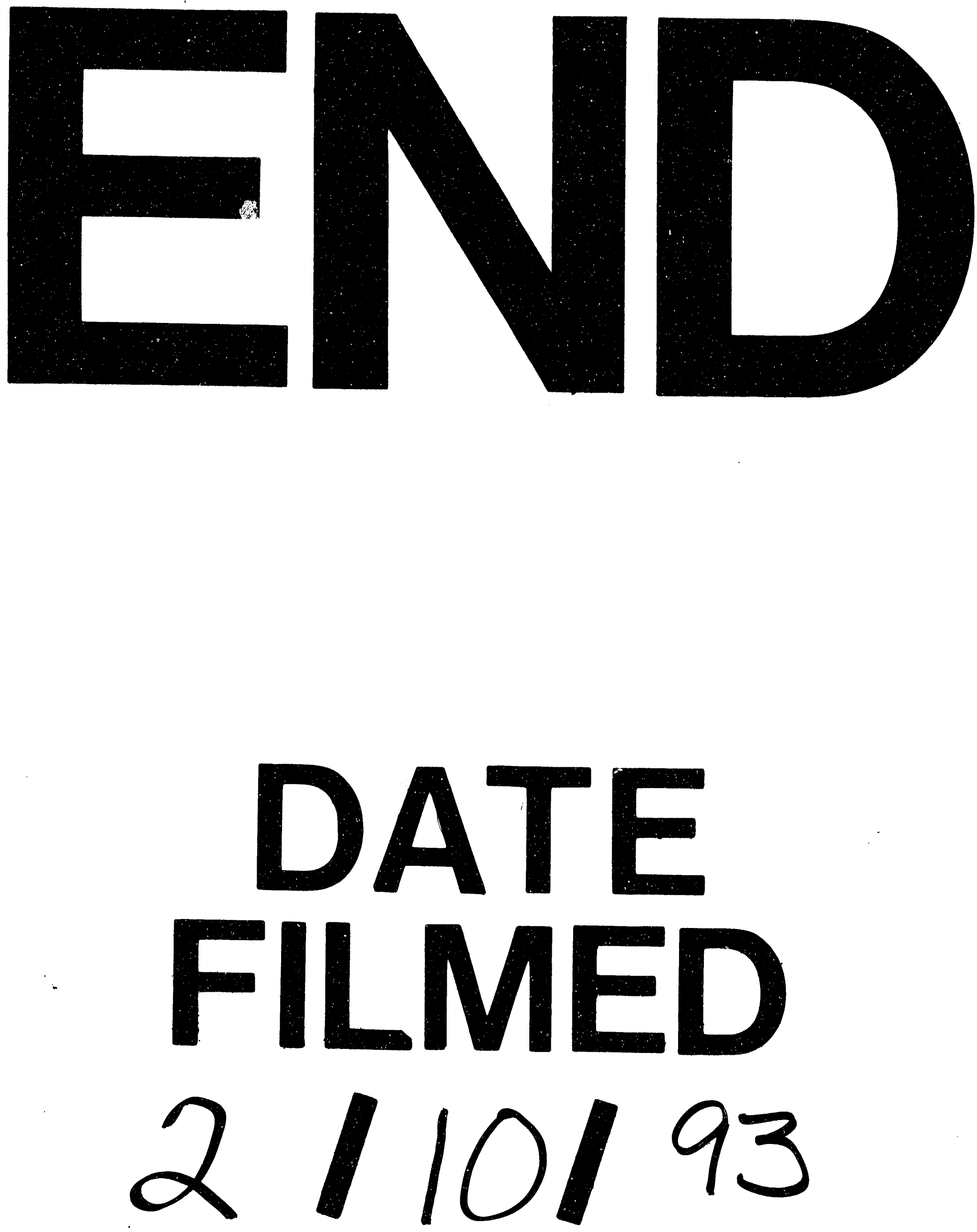